\title{
Multi-predictor mapping of soil organic carbon in the alpine tundra: a case study for the central Ecuadorian páramo
}

\author{
Johanna Elizabeth Ayala Izurieta ${ }^{*}$ (), Carmen Omaira Márquez ${ }^{3,4}$, Víctor Julio García ${ }^{3,5}$, \\ Carlos Arturo Jara Santillán ${ }^{1,6}$, Jorge Marcelo Sisti ${ }^{2}$, Nieves Pasqualotto ${ }^{1}$, Shari Van Wittenberghe ${ }^{1}$ and \\ Jesús Delegido'
}

\begin{abstract}
Background: Soil organic carbon (SOC) affects essential biological, biochemical, and physical soil functions such as nutrient cycling, water retention, water distribution, and soil structure stability. The Andean páramo known as such a high carbon and water storage capacity ecosystem is a complex, heterogeneous and remote ecosystem complicating field studies to collect SOC data. Here, we propose a multi-predictor remote quantification of SOC using Random Forest Regression to map SOC stock in the herbaceous páramo of the Chimborazo province, Ecuador.

Results: Spectral indices derived from the Landsat-8 (L8) sensors, OLI and TIRS, topographic, geological, soil taxonomy and climate variables were used in combination with 500 in situ SOC sampling data for training and calibrating a suitable predictive SOC model. The final predictive model selected uses nine predictors with a RMSE of $1.72 \%$ and a $R^{2}$ of 0.82 for SOC expressed in weight \%, a RMSE of $25.8 \mathrm{Mg} / \mathrm{ha}$ and a $\mathrm{R}^{2}$ of 0.77 for the model in units of $\mathrm{Mg} / \mathrm{ha}$. Satellite-derived indices such as VARIG, SLP, NDVI, NDWI, SAVI, EVI2, WDRVI, NDSI, NDMI, NBR and NBR2 were not found to be strong SOC predictors. Relevant predictors instead were in order of importance: geological unit, soil taxonomy, precipitation, elevation, orientation, slope length and steepness (LS Factor), Bare Soil Index (BI), average annual temperature and TOA Brightness Temperature.

Conclusions: Variables such as the BI index derived from satellite images and the LS factor from the DEM increase the SOC mapping accuracy. The mapping results show that over $57 \%$ of the study area contains high concentrations of SOC, between 150 and $205 \mathrm{Mg} / \mathrm{ha}$, positioning the herbaceous páramo as an ecosystem of global importance. The results obtained with this study can be used to extent the SOC mapping in the whole herbaceous ecosystem of Ecuador offering an efficient and accurate methodology without the need for intensive in situ sampling.

Keywords: Carbon stock mapping, Soil organic carbon (SOC), Landsat, Random forest regression, Vegetation indices, Multispectral indices
\end{abstract}

*Correspondence: joeai@alumni.uv.es

${ }^{1}$ Image Processing Laboratory (IPL), University of Valencia, 46980 Paterna, Valencia, Spain

Full list of author information is available at the end of the article

\section{Background}

Soil organic carbon (SOC) is the main component of soil organic matter (SOM), affecting essential biological, chemical and physical soil functions such as nutrient cycling, pesticide and water retention, and soil structure maintenance [1]. The accumulation of SOC is a slow process driven by environmental and climatic conditions. original author(s) and the source, provide a link to the Creative Commons licence, and indicate if changes were made. The images or other third party material in this article are included in the article's Creative Commons licence, unless indicated otherwise in a credit line to the material. If material is not included in the article's Creative Commons licence and your intended use is not permitted by statutory regulation or exceeds the permitted use, you will need to obtain permission directly from the copyright holder. To view a copy of this licence, visit http://creativecommons.org/licenses/by/4.0/. The Creative Commons Public Domain Dedication waiver (http://creativeco mmons.org/publicdomain/zero/1.0/) applies to the data made available in this article, unless otherwise stated in a credit line to the data. 
A sudden loss of SOC may therefore indicate soil degradation [2], land use changes or eventually also climate changes $[3,4]$. An alteration of $10 \%$ in the total of SOC in the world's soils is estimated to be equivalent to the anthropogenic $\mathrm{CO}_{2}$ emission over a 30-year time span [5]. Preserving the stock of SOC is therefore of global interest to the climate change mitigation and adaptation strategies [6]. Ecosystems with high amounts of SOC such as the Andean páramo, have a large potential to capture and store atmospheric $\mathrm{CO}_{2}$ [7]. The largest amount of SOC is typically stored into the top organic horizon layer of the soil $(0$ to $30 \mathrm{~cm})$, and gradual decreases towards deeper soil profile sections [8-11]. These organic soils have high water retaining capacity, and in turn they accumulate water from thawing, rain, and fog condensation. The accumulated water is further released to the lowlands providing essential ecosystem services for the larger region of these ecosystems [7, 12]. Identifying such priority ecosystems and quantifying their SOC stock is a priority for the climate goals. Likewise, monitoring the SOC content of these priority carbon-rich ecosystems can provide vital information for making correct decisions regarding land uses at a global scale [13-16]. Since annual changes in SOC are considered small compared to the SOC stocks, such continuous monitoring of SOC could be at intervals of $5-10$ years [8] in case robust prediction models are available.

The characteristics of these global SOC reservoirs are described by a set of soil biophysical and physical variables established by different fields [17]. Soil, vegetation and atmosphere characteristics, such as soil type and land use, together with climatic factors, land cover and topographic factors (including soil erosion) could be able to explain the dynamics of storage and the spatial distribution of SOC, being very useful especially in difficult geographical environments.

In the last years several methods have been used for SOC mapping, with the challenge to find the most appropriate and accurate one, based on study area characteristics and in situ data availability. Linear regression, geostatistical methods, and advanced nonlinear regression methods are used to predict the spatial distribution of the typically top layer soil properties [18]. Linear regression (simple and multiple) is used supposing a relationship between independent variables and the dependent variable under a linear form. Several studies used this method to estimate SOC, where the models explain up to $70 \%$ of the SOC variability $[19,20]$.

Geostatistical methods applied in soil mapping have the advantage of providing a statistically sound model for spatial variation, where the spatial autocorrelation is explicitly modelled and an explicit measure of the uncertainty is associated with the prediction [21, 22]. The limitations are due to the residuals which are assumed normally distributed, stationary and isotropic; in heterogeneous areas, the spatial variation models also fail to capture both gradual and abrupt changes in soil variation [22]. Therefore, in the large sample size the geostatistical models are computationally demanding [23]. Interpolations on data from in situ collected soil carbon such as ordinary kriging $(\mathrm{OK})$ can be an appropriate and quick option [24], assuming no underlying trend in the data. When there is a spatial structure in the model residuals, hybrid models like residual kriging are applied to improve the SOC prediction performance $[14,25,26]$. Here, auxiliary variables are exploited combining geostatistics with additional information for SOC predictions [27]. Regression kriging (RK) and universal kriging (UK) also are applied for SOC mapping, where the improvement of RK techniques over OK largely depends on the strength of the correlation between SOC and the ancillary variables $[28,29]$.

As an alternative, for more complex soil-environment relationships it is also possible to use machine learning (ML) regression algorithms [30]. ML techniques are non-linear data-driven algorithms, where no assumption of the observations' distribution is made. ML algorithms can also handle a large number of cross-correlated covariates as predictor variables [22]. Based on selflearning algorithms and supporting vector machines, ML techniques could further assist in the generation of even better calibration models for SOC prediction [10]. Also predictive tree models such as Classification and Regression Trees (CART) and Random Forest (RF) models [31] allow more accurate results and reduce the effect of noisy data [14, 32]. RF has demonstrated to provide reliable confidence intervals in SOC topsoil estimations [33]. In this context, RF models in combination with the appropriate selection of predictors can provide a powerful methodology for SOC mapping, applicable to both simple and complex geographical areas and when there a good data availability. Moreover, according to several authors adding new remote sensing predictors to the land cover analysis could greatly benefit the estimation of SOC distribution at diverse scales [10, 30, 34].

The soils of the Andean páramo ecosystem act as a large carbon sink due to its high capacity to retain SOC $[35,36]$. It has an elevation gradient between 3000 and $4000 \mathrm{~m}$ a.s.l., maintaining a constant cold climate which reduces the mineralization of organic matter $(\mathrm{OM})$ and produces large SOC reserves. Well-preserved soils in the ecosystem generally contain a larger amount of $\mathrm{OM}$ and therefore provide a greater storage capacity for carbon. Although the region is relatively well-conserved, human activities are present in the area, generally at lower elevations, where cattle is ranched and vegetation is often 
burned to grow pastures [37]. These changes in land use often produce significant losses in the soil carbon and reduce the capacity to further store carbon [38]. Despite the fact that studying the vast Andean páramo area and its changes on a regional scale is challenging due to the complexity given by its difficulty to access, the terrain irregularity, and the climatic conditions, the knowledge of this important carbon sink ecosystem is essential in the global attempt to quantify the SOC reserves and to make correct decisions on land uses [14]. However, digital SOC mapping studies for the region are scarce. In Ecuador, national-level knowledge of SOC reserves in this ecosystem is non-existent, and at the regional level it is limited or only punctually carried out [35]. The importance of herbaceous highland páramo ecosystems and their complex geography for sampling [36] have stimulated recent advances in methodologies for the estimation of SOC and its spatial distribution [39]. Finding good predictor variables for the spatial estimation of SOC which can be also remotely assessed is therefore considered of great scientific relevance.

In this respect, the objectives of this study are (1) to estimate and map SOC in the herbaceous páramo ecosystem based on a multi-predictor Random Forest (RF) regression technique applied to Landsat 8 (L8) satellite bands and indices in combination with complementary geographic information, (2) to identify the essential variables for SOC prediction, and (3) to evaluate the accuracy of SOC prediction in this complex mountain geosystem. To achieve these objectives, spectral bands and indices derived from the L8 sensors, OLI and TIRS, are combined with topographic variables from the digital elevation model (DEM), climate variables derived from the meteorological network in Ecuador and in situ collected SOC data to train and calibrate a self-learning algorithm with RF regression. The final step is the design of a SOC prediction model with a good level of accuracy used to map the spatial distribution of SOC in the study area.

\section{Materials and methods Study area}

The study is carried out for herbaceous páramo ecosystem in the province of Chimborazo, Ecuador [40], $135 \mathrm{~km}$ south of the Quito city, and located in the central zone of the country. The ecosystem covers the largest area of mountain ecosystems in Ecuador, extending along the Andean mountain range, which borders the Western and Eastern Cordilleras arranged in meridian direction [7], from the province of Carchi to the province of Loja $[41,42]$.

The herbaceous páramo is the largest subtype from sixteen subtype of páramo in Ecuador and cover above 75\% approximately of the Ecuadorian páramo region [41, 42].
It extends between $78^{\circ} 39^{\prime}$ west longitude and $1^{\circ} 39^{\prime}$ south latitude (Fig. 1). It is a mountainous geosystem with an irregular topography and elevation range between 2303 and $4501 \mathrm{~m}$ a.s.l, with a mean elevation of $3838 \mathrm{~m}$ a.s.l. Dry and wet seasons occur without notable differences, and the diurnal temperature change is most important as the annual changes of the mean temperature [43]. The mean annual temperature is $11{ }^{\circ} \mathrm{C}$ and a high cloudiness is typical for this type of mountain ecosystem. The study area has $1667.6 \mathrm{~km}^{2}$, being $25.7 \%$ of the total province surface. The climatic and soil conditions are characterized by high humidity levels and high concentration of SOC. This results as a large amount of water per unit volume and an excellent water regulation capacity, between 0.55 and $0.90 \mathrm{~cm}^{3} \mathrm{~cm}^{-3}[7,42,44]$.

\section{Field data}

In situ SOC data was collected between August 2016 and November 2017. Soil samples were taken from the top surface horizon layer $(0$ to $30 \mathrm{~cm})$. Specifically, 500 points (for training and testing) were sampled with their respective geographical position (UTM coordinates zone 17S, WGS84) (PGS-Trimble JUNO SB handheld with 2-to5 - $\mathrm{m}$ positional accuracy in real time), and the $\mathrm{SOC}$ value was obtained in units of weight/weight \% ( $\mathrm{g} \mathrm{C} / 100 \mathrm{~g}$ of soil) and units of $\mathrm{Mg} / \mathrm{ha}$ (Fig. 1). In order to carry out a post-validation of the model, 29 additional points were randomly sampled in July 2018 for a post-validation test, obtaining a total of $529 \mathrm{SOC}$ points.

It is essential to have a large dataset to identify the ideal conditions that allow to find an excellent quantification of the SOC distribution over the study area. To find variables or indicators of SOC enables the possibility not only of obtaining a predictive model, as shown in the development of this article, but also, knowing the relationship between environmental variables with the storage dynamics of the SOC.

The SOC dataset (500 sample points for training and testing and 29 additional points of post-validation) is the result of a stratification of sampling units on the herbaceous páramo ecosystem, taking into account the geology and taxonomy of the soil available in the national system of geographic information [45]. Also, a review of the sampling units was made using the NDVI distribution (NDVI range between -0.1 and 0.8 , with a mean value around 0.4) to look at aspects of vegetation cover and variations, also an in situ survey of the sampling units was carried out as information to define the monitoring points. For that, topography, vegetation cover and the access to the entire ecosystem territory was considered, but the difficulty to access (ballast roads and some trails with steep slopes) was high or even impossible for some areas. Although we take the 


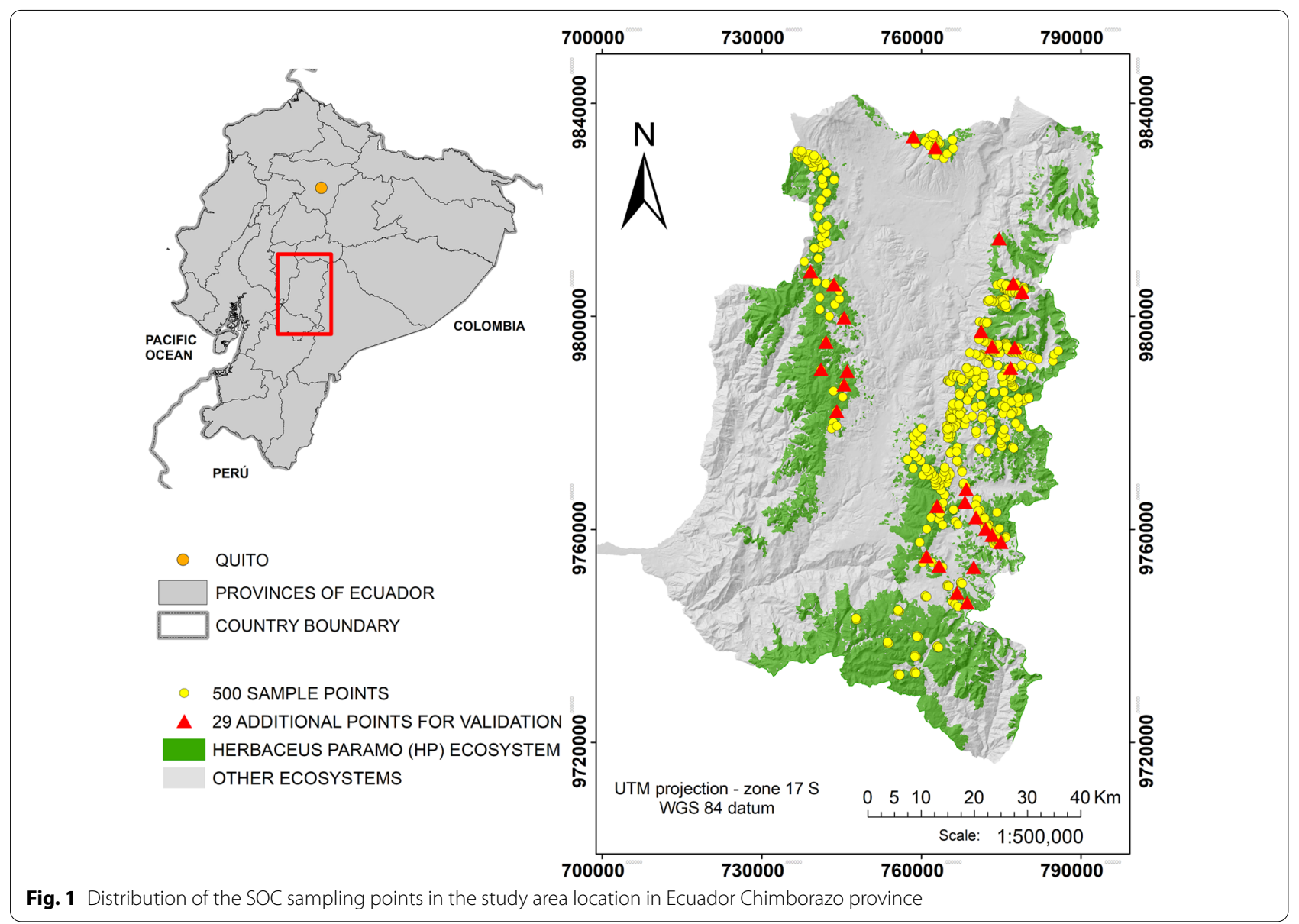

samples for training from August 2016 to November 2017, Wadoux et al. [46] confirmed the importance of the covariates used in the RF model more recently. Also, Wadoux et al. [46] have shown that the differences between prediction accuracies of different samples designs for large sample sizes become negligible.

For this reason, a random sampling was performed with a 95\% confidence level. In situ samples were collected from 0 to $30 \mathrm{~cm}$ below ground using a blast-hole. Additional samples were taken at each site to determine the soil bulk density (in $\mathrm{g} / \mathrm{cm}^{3}$ ), which was determined with $88 \mathrm{~cm}^{3}$ cylinders, taking undisturbed soil samples [47]. Soil samples were sieved ( $2 \mathrm{~mm}$ mesh), oven-dried at $105{ }^{\circ} \mathrm{C}$ for $24 \mathrm{~h}$, and ground prior to analysis. The total SOC in the collected soil samples was determined with an Elemental Analyzer (Flash 2000 Organic Elemental Analyzer type CHNS/O, ThermoFicher Scientific). Specifically, a soil aliquot, containing approximately $10 \mathrm{mg}$ of organic carbon in silver capsules, was weighed [48, 49]. The soil bulk density was calculated using the known volume cylinder method [50]. From the soil sample SOC weight \% obtained (g C/100 g of soil) and the soil bulk density of the sample, the SOC content was expressed in $\mathrm{Mg} / \mathrm{ha}$ [51].

\section{Satellite image processing}

The multispectral images used in this study correspond to the Landsat- 8 satellite (L8), obtained by the Operational Land Imager (OLI, bands 3 to 7) and the Thermal Infrared Sensor (TIRS, band 10 and 11) sensors. L8 images were downloaded from the Global Visualization Viewer (GloVis) web service of the United States Geological Survey [52]. The images used are from two L8 scenes, with approximately $75 \%$ of the study area located in the North scene, for which, the base image was LC80100612016325LGN01 (Table 1). It was also necessary to select two other scene dates for the gap filling, due to the large cloud cover in these base scenes. Based on a low annual meteorological variability (constant wet cold weather) typical of the páramo grasslands $[7,53]$, and the relatively stable SOC between consecutive years based on weather information available from the study area [45], images from the next year with similar dates were used for the filling on the North scene. 
Table 1 Landsat-8 images used

\begin{tabular}{lllll}
\hline L8 scene ID & Date & Use-path, row (WRS-2) & \% CC $^{\mathbf{a}}$ & Qlty $^{\mathbf{b}}$ \\
\hline LC80100612016325LGN01 & $2016 / 11 / 20$ & Base image (North scene)-010, 061 & 19.78 \\
LC80100622016325LGN01 & $2016 / 11 / 20$ & Base image (South scene)-010, 062 & 25.59 \\
LC80100612017263LGN00 & $2017 / 09 / 20$ & Filling-010, 061 & 32.44 & 9 \\
LC80100612017023LGN01 & $2017 / 01 / 23$ & Filling-010, 061 & 57.94 & 9
\end{tabular}

a Cloud cover (CC) percentage

b Image quality for the bands ( $9=$ best, $0=$ worst, $-1=$ not calculated) (QIty)

The images were downloaded in GEOTIFF format, presenting a L1T pre-processing level, i.e., images with radiometric and geometric systematic correction by means of the incorporation of the ground control points [54] and ortho-rectification through the DEM. A verification was made by means of topographic maps and base cartography of rivers and roads, at a scale of 1:50,000, georeferenced in the UTM Datum WGS84 projection, from the Military Geographic Institute of Ecuador [55].

The downloaded satellite images contain the spectral information stored in digital numbers (DN) from the 16-bit L8 sensors to be converted to physical units such as radiance and reflectance. A radiometric calibration was applied through the Radiometric Calibration tool of the software ENVI 5.1 [56] to obtain radiance values at the top of the atmosphere (TOA). TOA radiance values were after converted to surface reflectance values by means of the FLAASH Atmospheric Correction tool also of ENVI 5.1, to remove the atmospheric dispersion based on two factors, (1) the radiance reflected by the canopy or earth surface to the sensor, and (2) the radiance that is dispersed by the atmosphere before arriving at the sensor.

Due to the climatic and atmospheric conditions, the mountainous páramo areas are highly affected by cloud presence. For this reason, the histogram of the images was analysed for cloud screening. Next, clouds were removed using the 16-bit Quality Assessment band to generate a mask, the Quality Assessment band is equal in size to the bands of the L1T product. This band has a decimal value at each pixel that represents the combinations of surface fill bits, atmosphere and sensor conditions that can affect the overall usefulness of a pixel [57].

Finally, the image mosaic was generated by means of the processed image of the scene LC80100612016325LGN01 that covers the north, center and part of the south zone of the study area and the processed image of the scene LC80100622016325LGN01 that covers the South zone. Cloud cover pixel gaps were filled in by the processed scenes LC80100612017263LGN00 and LC80100612017023LGN01 (Table 1).

Temperature was studied by means of the TIRS sensor [57], using the mean of bands 10 and 11. The top of atmosphere brightness temperature, TOA Brightness
Temperature, is obtained in Kelvin (K) and converted to its corresponding value in degrees Celsius $\left({ }^{\circ} \mathrm{C}\right)$. The annual variation in meteorological air temperature of the páramo is low [58], so, likewise the mosaic of the optical OLI sensor images, a mosaic of the TIRS band information was made with the images mentioned in Table 1.

\section{Spectral indices}

Few studies use satellite sensors for SOC estimation [59]. However, the soil and the above-ground environment can be closely related allowing us to understand the biological, chemical and physical processes that govern the soil functions [60]. In recent years, however, SOC estimation and mapping based on remote sensing data are undergoing major developments including the use of new variable predictors [34]. In this regard, spectral indices can describe the surface characteristics in terms of vegetation cover, land use, and its changes. These characteristics can be further related to the soil properties and the soil type, such as soil moisture, and possibly establish covariance with SOC storage data [61, 62], by its influence into the global cycle of carbon [16, 63]. Different studies use the visible region considering that soils with higher carbon content have a darker appearance [63]. An extended literature review on remote sensing SOC estimates shows that different authors obtain good results in the $400-2200 \mathrm{~nm}$ spectral range [34, 64-68]. Here we use L8 OLI and TIRS spectral bands in the visible, near-infrared and thermal region (range 10.6 to $11.19 \mu \mathrm{m}$ and 11.5 to $12.51 \mu \mathrm{m}$ ) to calculate spectral indices that are evaluated as possible indicators of SOC sequestration including indices related to the vegetation and soil moisture (NDVI, SAVI, WDRVI, EVI2, VARIg, NDMI), water (NDWI), bare soil (BI), snow cover (NDSI) and burnt soil (NBR, NBR2) in the case of the OLI sensor, and temperature in the case of the TIRS sensor (TOA Brightness Temperature). Table 2 shows the name, formulation and source of the spectral indices used.

\section{Meteorological, topographical, geological and taxonomic data Meteorological and climatic data}

The SOC level in the soil is related to the amount of OM [83], which mainly depends on temperature, since at low 
Table 2 Established vegetation indices used in this study

\begin{tabular}{|c|c|c|}
\hline Index/references & Formula & Formula with specific L8 bands \\
\hline Normalized Difference Vegetation Index_NDVI [69] & $N D V I=\frac{N I R-R}{N I R+R}$ & $N D V I=\frac{B 5-B 4}{B 5+B 4}$ \\
\hline Soil-Adjusted Vegetation Index_SAVI [70], L value according [71] & $\begin{array}{l}S A V I=\frac{N R R-R}{N \| R+R+L}(1+L) \\
L=0.15\end{array}$ & $\mathrm{SAVI}=\frac{\mathrm{B} 5-\mathrm{B} 4}{\mathrm{~B} 5+\mathrm{B} 4+0.15}(1+0.15)$ \\
\hline Wide Dynamic Range Vegetation Index_WDRVI [72], a value according [71] & $\begin{array}{l}\text { WDRVI }=\frac{a N I R-R}{a N I R+R} \\
a=0.05\end{array}$ & WDRVI $=\frac{0.05 B 5-B 4}{0.05 B 5+B 4}$ \\
\hline Enhanced Vegetation Index 2-EVI2 [73] & $\mathrm{EVI} 2=2.5 \frac{\mathrm{NIR}-\mathrm{R}}{\mathrm{NIR+2.4R+1}}$ & $\mathrm{EVI} 2=2.5 \frac{\mathrm{B} 5-\mathrm{B} 4}{\mathrm{~B} 5+2.4 \mathrm{~B} 4+1}$ \\
\hline Normalized Difference Water Index_NDWI [74] & $\mathrm{NDWI}=\frac{\mathrm{G}-\mathrm{NIR}}{\mathrm{G}+\mathrm{NIR}}$ & $\mathrm{NDWI}=\frac{\mathrm{B} 3-\mathrm{B} 5}{\mathrm{~B} 3+\mathrm{B} 5}$ \\
\hline Visible Atmospherically Resistant Vegetation Index green—VARIg $[75,76]$ & $V A R I_{G}=\frac{G-R}{G+R}$ & $V A R I_{G}=\frac{B 3-B 4}{B 3+B 4}$ \\
\hline Normalized Difference Snow Index_NDSI [77] & $N D S I=\frac{S W 1 R 1-N I R}{S W I R 1+N I R}$ & $\mathrm{NDSI}=\frac{\mathrm{B} 6-\mathrm{B} 5}{\mathrm{~B} 6+\mathrm{B} 5}$ \\
\hline Bare Soil Index- BI [78] & $B \mid=\frac{(S W I R 1+R)-(N I R+B)}{(S W R 1+R)+(N \mid R+B)}$ & $\mathrm{BI}=\frac{(\mathrm{B} 6+\mathrm{B} 4)-(\mathrm{B} 5+\mathrm{B} 2)}{(\mathrm{B} 6+\mathrm{B} 4)+(\mathrm{B} 5+\mathrm{B} 2)}$ \\
\hline Normalized Difference Moisture Index—NDMI $[79,80]$ & $N D M I=\frac{N I R-S W \mid R 1}{N|R+S W| R 1}$ & $\mathrm{NDMI}=\frac{\mathrm{B} 5-\mathrm{B} 6}{\mathrm{~B} 5+\mathrm{B} 6}$ \\
\hline Normalized Burn Ratio_NBR [81] & $N B R=\frac{N I R-S W I R 2}{N I R+S W R 2}$ & $N B R=\frac{B 5-B 7}{B 5+B 7}$ \\
\hline Normalized Burn Ratio 2-NBR2 [82] & $N B R 2=\frac{S W I R 1-S W I R 2}{S W I R 1+S W I R 2}$ & $\mathrm{NBR} 2=\frac{\mathrm{B} 6-\mathrm{B} 7}{\mathrm{~B} 6+\mathrm{B} 7}$ \\
\hline TOA Brightnees Temperature [57] & $\begin{array}{l}T=\frac{\mathrm{K} 2}{\ln \left(\frac{\mathrm{K} 1}{\mathrm{~L}_{\lambda}}\right)+1} \\
T=\mathrm{TOA} \text { Brightness Tempera- } \\
\text { ture } \\
\mathrm{L}_{\lambda}=\text { spectral radiance } \\
\mathrm{K} 1 \text { y } \mathrm{K} 2=\text { thermal conversion } \\
\text { constants }\end{array}$ & B10, B11TIRSsensor \\
\hline
\end{tabular}

temperatures biological activity is reduced, reducing the mineralization of the $\mathrm{OM}$ and allowing its accumulation in large quantities. Both temperature and precipitation are moreover determining the distribution and growth of vegetation making them very important control variables for both biomass growth and carbon storage in the soil [42].

The temperature at the páramo generally decreases between $0.5{ }^{\circ} \mathrm{C}$ to $0.7{ }^{\circ} \mathrm{C}$ for each $100 \mathrm{~m}$ of elevation (from $2000 \mathrm{~m}$ a.s.l) [53]. Data on air temperature and precipitation are collected by the weather stations in the area (Fig. 2). The seasonal trend in temperature and precipitation data of the study area in practically equatorial territory show only small alterations in time, indicating humid and cold conditions with small fluctuations $<2{ }^{\circ} \mathrm{C}$ on a yearly basis, with month average temperatures commonly low $10{ }^{\circ} \mathrm{C}$ [40]. Therefore, it was decided to use the average annual air temperature data, as well as the total precipitation for the 2015 year, from the meteorological stations closest to study zone, taking into account the availability, quantity and quality of the data. The data from meteorological stations located within the Chimborazo province is provided by the National Institute of Meteorology of Ecuador (INAMHI, 21 stations), the data from the southeast of the Chimborazo province by the National University of Chimborazo (UNACH, 3 stations) (Fig. 2), and additional data from 33 meteorological station belonging to INAMHI located in surrounding areas out of the study area. Spatial interpolation methods are used to obtain weather information at a particular place where it can't be attained directly [84]. Ordinary kriging stochastic interpolation method is widely used for spatial interpolation of meteorological data $[24,85]$. We generated distribution layers of the surface variables through geostatistical analysis with the OK method and with a semivariogram adjustment taking into account the spatial variation of relationships between stations [84]. Most part of the study zone has an average annual temperature between 8 and $14{ }^{\circ} \mathrm{C}$, with minimum of average temperature of $5{ }^{\circ} \mathrm{C}$ and a mean around $11{ }^{\circ} \mathrm{C}$. The annual accumulation of precipitation in the study area has a minimum and maximum of $390 \mathrm{~mm}$ and $2380 \mathrm{~mm}$, respectively.

\section{Topographic data}

Soil erosion can alter and change the SOC by causing a significant loss of relatively stable and long-term stored SOC in the top soil layers [86]. From the DEM, the slope and orientation variables were analyzed and, in order to evaluate the effect of soil erosion, the dimensionless Slope Length and Steepness Factor (LS Factor) variable was calculated [87].

The LS Factor describes the topographic effect on the soil erosion, and it incorporates the potential for soil erosion due to surface runoff. This is based on two factors; the factor $\mathrm{L}$ informs about the impact of the length of the 


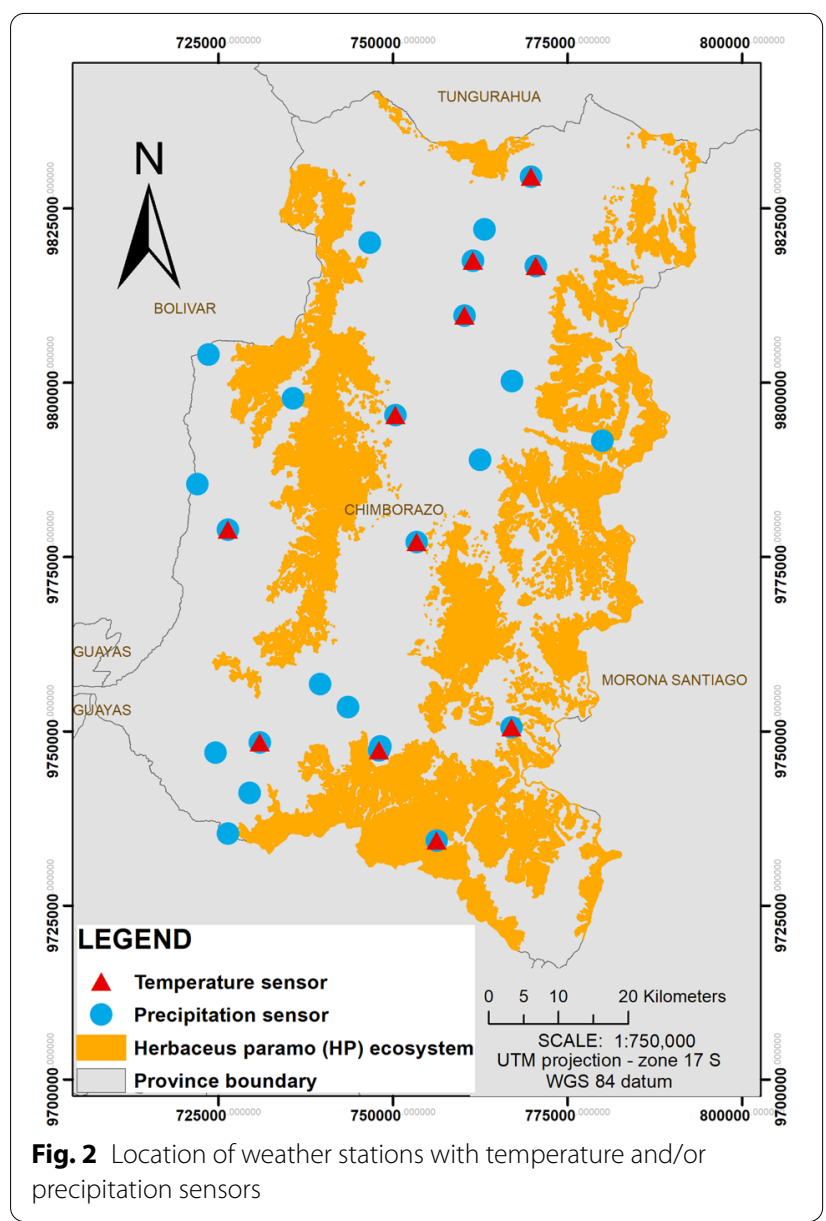

slope while the factor S explains the effect of the slope's inclination. This factor is appropriate for estimating landscape erosion in complex topographies. The procedure was performed in ArcGis 10.2 software applying Eqs. 1, 2, $3,4,5$ and 6 [88].

$$
L S=L * S
$$

with the $\mathrm{L}$ factor calculated as:

$$
\begin{aligned}
& \beta=\frac{\frac{\sin \theta}{0.0896}}{3 \sin \theta^{0.8}+0.56} \\
& m=\frac{\beta}{\beta+1} \\
& L=\frac{\left[A_{i, j}+D\right]^{(m+1)}-A_{i, j}{ }^{(m+1)}}{x^{m} D^{m+2}(22.13)^{m}}
\end{aligned}
$$

where $A_{i, j}$ is the accumulation area with coordinates (i,j) $\left[\mathrm{m}^{2}\right]$; $\mathrm{D}$ is the length of the pixel size $[\mathrm{m}] ; \mathrm{x}$ is the shape coefficient [dimensionless]; $\mathrm{m}$ has values between 0 and 1 [dimensionless]; $\theta$ is the slope angle [rad]; and $\beta$ is the ratio of rill to interill erosion [dimensionless].

The $\mathrm{S}$ factor is calculated as:

$$
\begin{aligned}
& S=10.8 \sin \theta+0.03, \quad \text { if } \operatorname{tg} \theta<0.09 \\
& S=16.8 \sin \theta-0.05, \quad \text { if } \operatorname{tg} \theta \geq 0.09
\end{aligned}
$$

\section{Geological and soil taxonomic data}

The geological classification of the soil is based on its origin and evolution over time. The national geological mapping classification was used [45] containing 31 geological unities with names referring to the site locations (Fig. 3a).

There are soils of volcanic origin, which would have a high content of OM. On the outer slopes there are perennial forested areas, often with thick cloud cover present. These soils are partially covered by recent volcanic ash and rejuvenated by the soil erosion. There are also soils with sediments of recent and long-standing volcanic origin. Similarly, alluvial soils with some agricultural activity occur [7]. These characteristics and geological conditions in the páramo herbaceous soils may favor the storage of SOC in high quantities.

Further, the variable layer of the soil taxonomy was included. According to this variable, the soil is considered as a natural body comprising solids (minerals and $\mathrm{OM}$ ), liquids and gases on the land surface. It is characterized by horizons or layers distinguished from the initial material as a result of additions, losses, transfers and transformations of energy, also by the ability to support plants in a natural environment. To categorize the soil based on their taxonomy, the USDA Soil Taxonomy was used, recognized in Latin America [89]. The soils in the study area include predominately Andosols, together with Entisols, Histosols, Inceptisols and Mollisols (Fig. 3b). Due to the volcanic origin of these soils, they have high OM and SOC content, differences in SOC stock capacity can be evaluated based on this taxonomy variable.

\section{SOC prediction with Random Forest Regression}

For the SOC prediction Random Forest (RF) regression was used (Salford Systems software, version SPM8.2). $\mathrm{RF}$ is a combination of tree predictors and formed by growing a tree structure depending on a random vector while the tree predictor takes on numerical values [31]. RF regression was performed to obtain the quantitative value of SOC, with taking numerical values instead of class labels as tree predictors and the training set is independently extracted from the random vector distribution. 


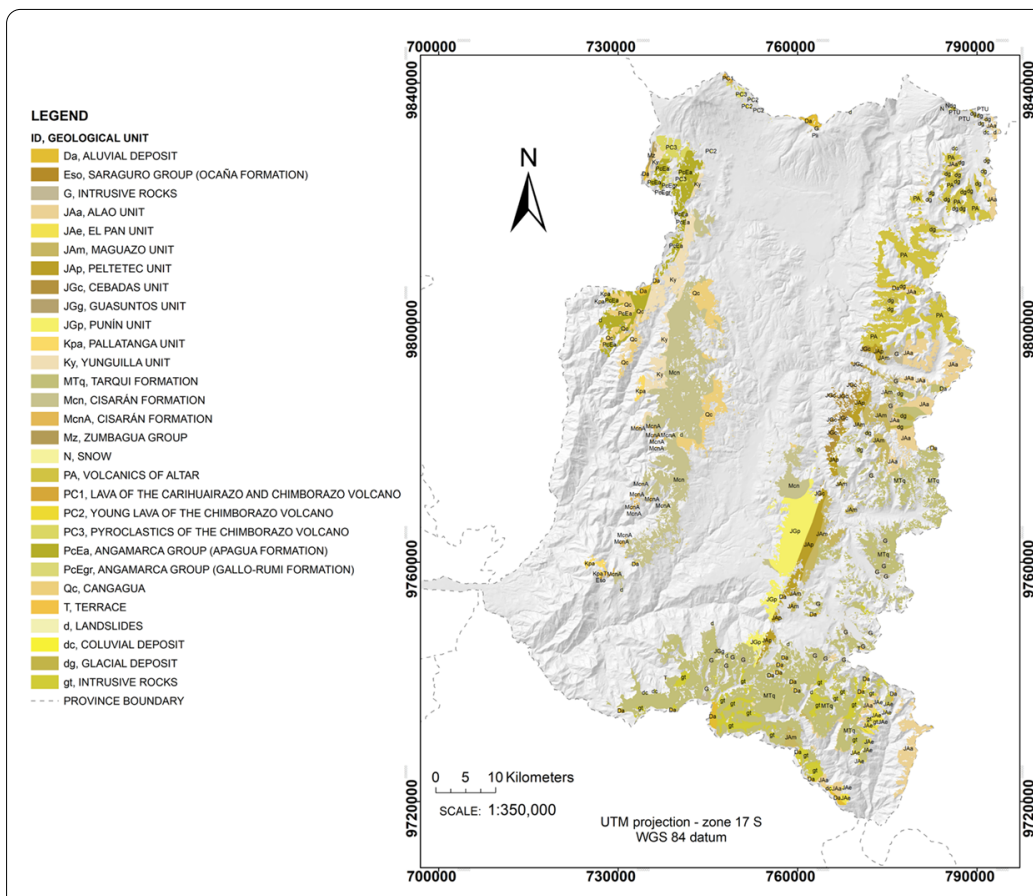

a)

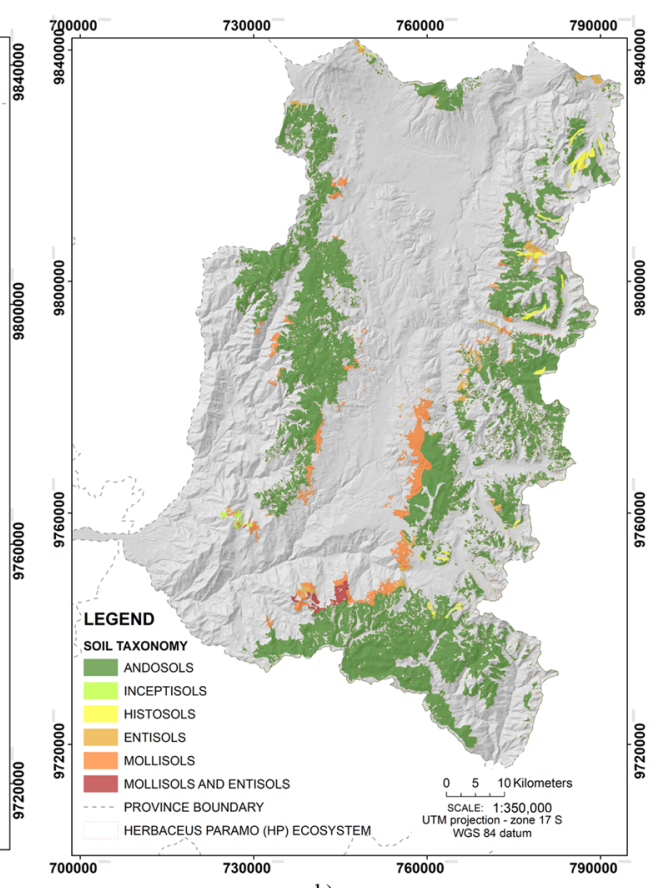

Fig. 3 a Geological unities map of the páramo herbaceous ecosystem; b Soil taxonomic map under the páramo herbaceous ecosystem in the study area

One of the advantages of RF is that it is robust despite the presence of noise, i.e. the presence of anomalous data [31]. The algorithm is based on classification and regression trees (CART) [90, 91]. The CART finds the variables with predictive possibility and the division points that reduce the quadratic and absolute error in order to predict the dependent variable SOC with greater accuracy. CART evaluates all possible predictors and all possible split points for each predictive variable and determines the best split for each one, making a comparison between the best splits of each possible predictor and choosing the split based on the standard deviation of each option. In Fig. 4a, the process followed by a CART algorithm to find the best break or split point in the tree is shown.

Therefore, the RF regression algorithm adjusts multiple CART trees to independent sample bootstrap data and then combines the predictions. A bootstrap is a random sample for replacement purposes, it is created by randomly selecting one record at a time from the original data, an observation can be chosen more than once. The process is carried out until the same number of records of the original data are completed. A CART tree is created in each bootstrap, and only $\mathrm{K}$ variables selected randomly are considered in each partition of the tree instead of all of them. The process is performed $M$ times according to the number of bootstraps created. At the end a prediction record for each tree is obtained, and the final prediction is the result of the average of $\mathrm{M}$ predictions. The performance of the algorithm depends on parameters such as $K$ and $M$, set in this study. In this way the $\mathrm{RF}$ prediction is an average of the prediction of the CART trees created in each bootstrap (from 1-M) (Fig. 4b). Each of the records of the matrix are submitted down each bootstrap decision tree, generating at the end of its step a prediction based on the bootstrap CART (1-M).

\section{Model training, optimization and calibration process}

The methodology used to calibrate the RF regression algorithm for the prediction model is summarized in Fig. 5a. The training and calibration dataset was created based on the extraction of all prediction variables to the 500 in situ SOC sample X, Y coordinates. 315 SOC samples were used for training and 185 for calibration Out of Bag (OOB). The training of the prediction model uses sets of variables based on different combination ways to evaluate their predictive functionality. In total 20 variables are evaluated as possible SOC predictors in this study (see Table 3), including spectral variables (EVI2, WDRVI, SAVI, NDVI, NDWI, VARI ${ }_{G}$, NDSI, BI, NDMI, NBR, NBR2, TOA Brightness Temperature (TBrT)), topographic variables (elevation, LS Factor, slope and orientation), climatic variables (average annual air temperature and precipitation), and variables corresponding to Ecuador's soil base mapping (geological unit and soil taxonomy). The use of the variables was jointly and 


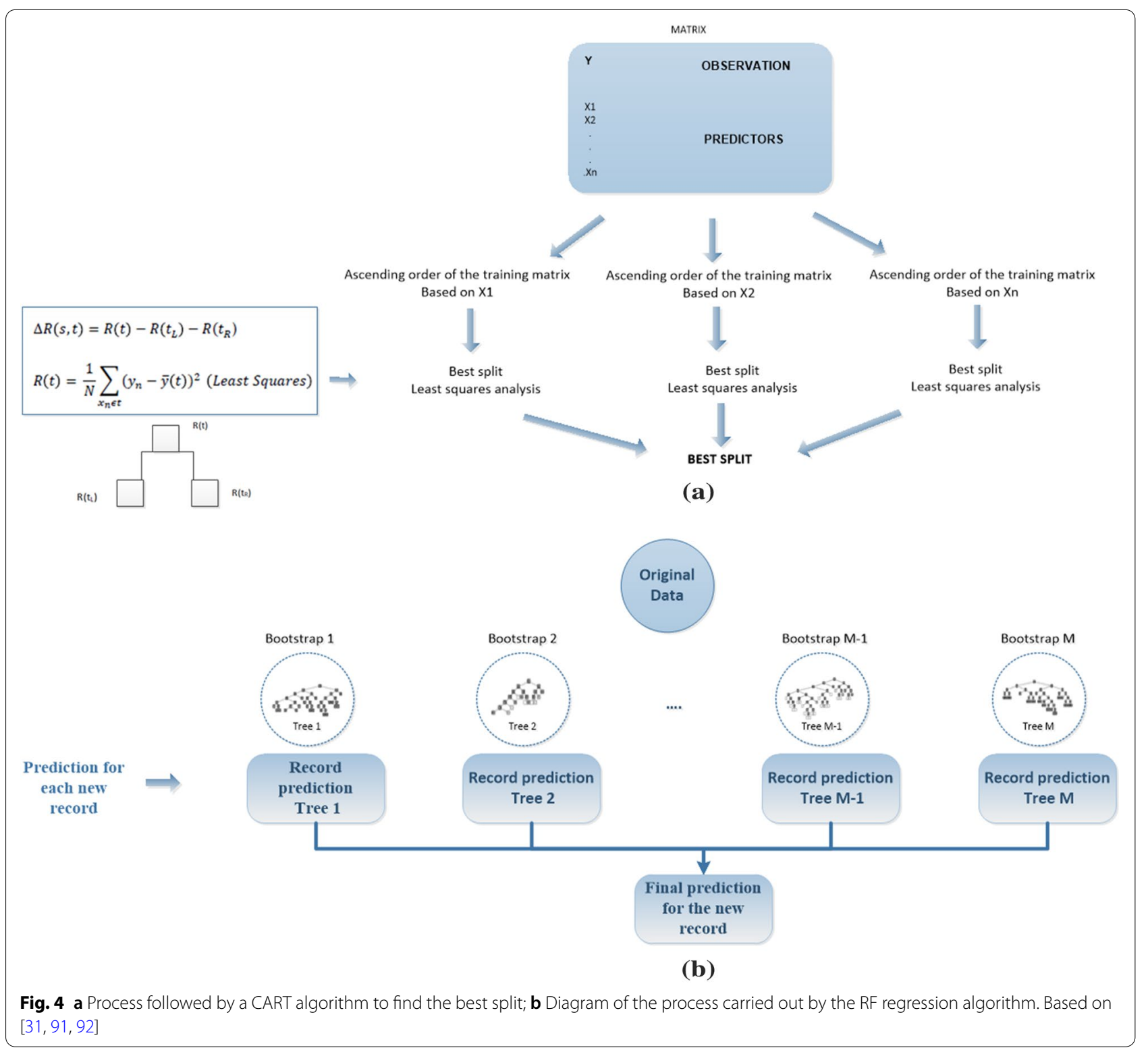

Table 3 Characteristics of variables evaluated as possible SOC predictors

\begin{tabular}{|c|c|c|c|}
\hline Type of variable & Variable & $\begin{array}{l}\text { Spatial } \\
\text { resolution/ } \\
\text { scale }\end{array}$ & Source \\
\hline Spectral & $\begin{array}{l}\text { Indices: EVI2, WDRVI, SAVI, NDVI, NDWI, VARIG, } \\
\text { NDSI, BI, NDMI, NBR, NBR2 }\end{array}$ & $30 \mathrm{~m}$ & Landsat 8 images_OLI sensor (see Table 1) [57] \\
\hline Spectral & TOA Brightness Temperature (TBrT) & $100 \mathrm{~m}$ & Landsat 8 images_-TIRS sensor (see Table 1) [57] \\
\hline Topographical & Elevation, LS Factor, Slope, Orientation & $30 \mathrm{~m}$ & DEM Ecuador-SNI Ecuador [45] \\
\hline Climatic & Average annual air temperature, precipitation & - & $\begin{array}{l}\text { Interpolations using data of meteorological stations } \\
\text { (54 stations belonging to INAMHI and } 3 \text { belonging to } \\
\text { UNACH) }\end{array}$ \\
\hline Geological and soil taxonomic & Geological Unit, Soil Taxonomy & $1: 50,000$ & Geology, taxonomy of Ecuador-SNI Ecuador [45] \\
\hline
\end{tabular}




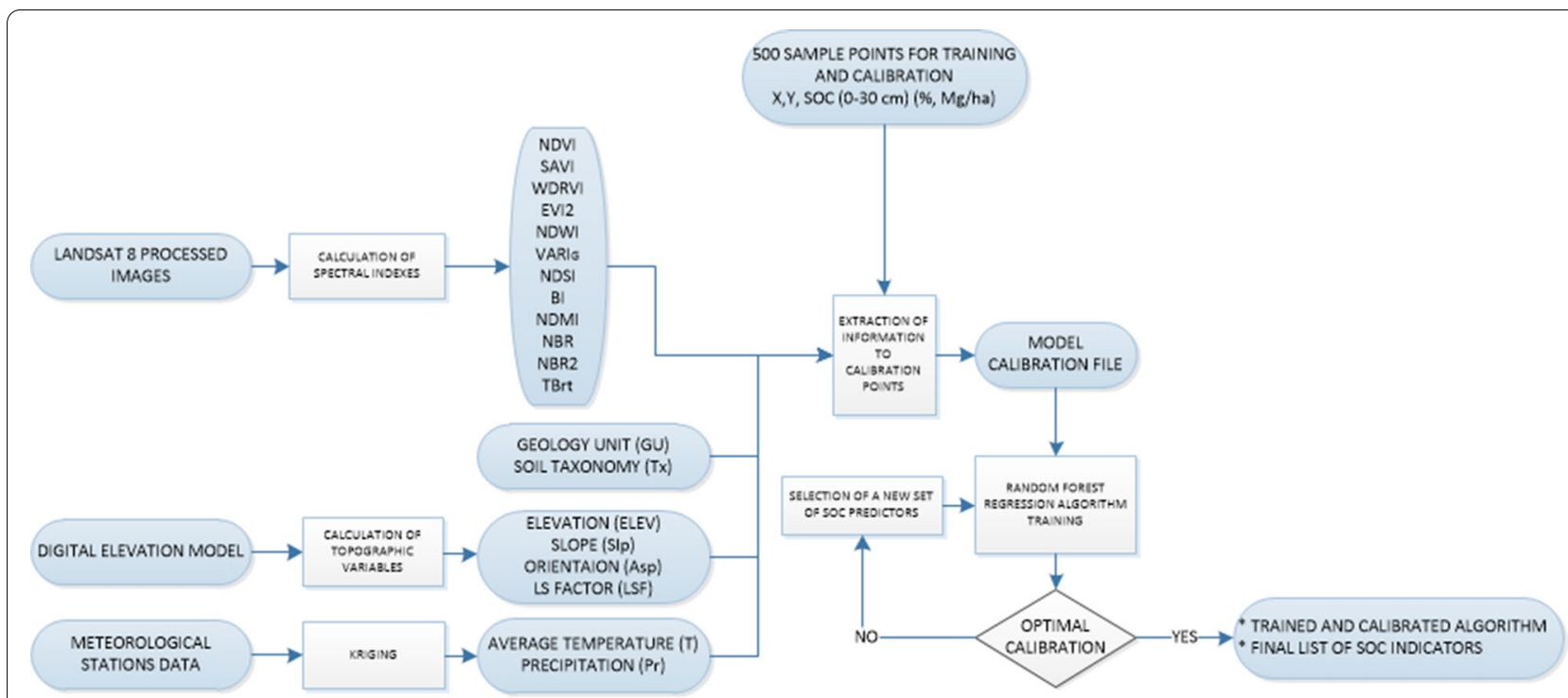

(a)

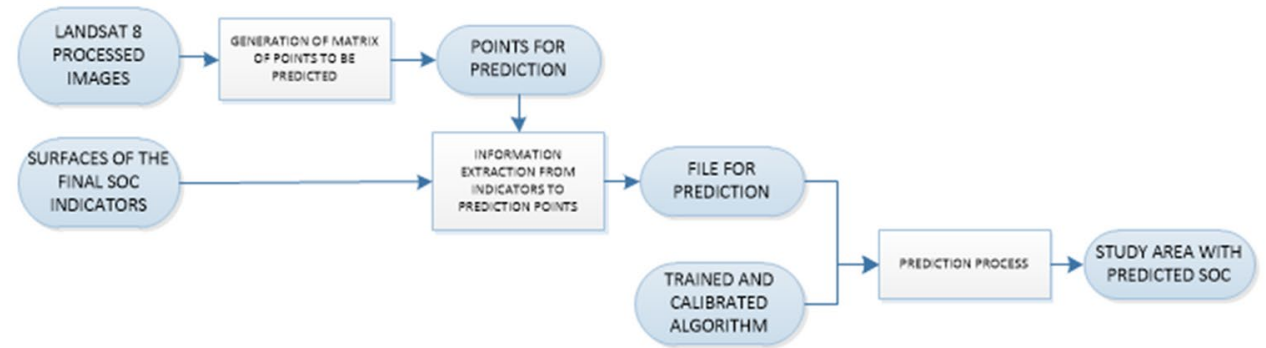

(b)

Fig. 5 a Methodology for generating the SOC prediction model through the Salford Systems software SPM8.2; $\mathbf{b}$ Application of the trained and calibrated SOC algorithm for SOC pixel-based prediction mapping in the study area

thus also through combined subgroups, to rule out nonuseful variables and to optimize the model. The model calibration starts with all variables (20). Then, variables with less relative importance are discarded, these variables provide limited information to improve the model. The number of tree nodes used is adjusted when the RMSE is stable, the final model is obtained when the maximum determination coefficient $\left(R^{2}\right)$ was reached (Eqs. 7, 8 and 9). The Mean Squared Error (MSE) (Eq. 10), Mean Absolute Deviation (MAD) (Eq. 11) and Mean Absolute Percentage Error (MAPE) (Eq. 12) also were observed.

$$
\begin{aligned}
& R^{2}=1-\frac{S S E}{S S Y} \\
& S S Y=\sum_{i}^{n}\left(y_{i}-\bar{y}\right)^{2}
\end{aligned}
$$

$$
\begin{aligned}
& S S E=\sum_{i}^{n}\left(y_{i}-f_{i}\right)^{2} \\
& M S E=\frac{S S E}{n} \\
& M A D=\frac{\sum_{i}^{n}\left|y_{i}-f_{i}\right|}{n} \\
& M A P E=\frac{100}{n} \sum_{i}^{n} \frac{\left|y_{i}-f_{i}\right|}{f_{i}}
\end{aligned}
$$

where SSY is the total sum of squares; and SSE is the sum of squares of residuals; $y_{i}$ is the observed value; $f_{i}$ is the predicted value; $\bar{y}$ is the mean of the observed data; and $n$ is the number of sample points.

Concretely, the accuracy of each SOC prediction model is obtained after the algorithm calibration based on the 
OOB dataset, which are about one-third of the datapoints left out conforming the OOB for each bootstrap [31]. Each OOB record is subjected to the algorithm as it passes through its decision trees and its accuracy is recorded. Similarly, the OOB dataset is used to evaluate the importance of each predictor variable to optimize the model, obtaining the precision and an indicator of the variable importance for the model [71]. Each variable is evaluated individually considering the decrease in precision when erroneous values are entered, then the variables are rescaled to have values between 0 and 100 (for each variable). The most important variable is given $100 \%$ while the rest of variables are relatively expressed to this one [31].

To predict the SOC for each pixel, the spatial resolution of the satellite images was used to create a homogeneous spatial distribution of points in the study area, and with their respective associated coordinates (X, Y), forming the prediction file. Then, predictors data values are extracted into the prediction file. Each record is evaluated into the model of SOC prediction generated, finally the quantitative value of SOC content for each pixel in the study area is predicted (see Fig. 5b).

In addition to the calibration of the predictions validated through OOB, a final independent validation process was carried out with additional in situ data not used in the training/calibration and not used on the OOB. For this purpose, post-validation sample points were used ( 29 additional points, detailed in Sect. 2.2), obtaining the real value of SOC through a laboratory analysis. Twenty-nine validation points collected in 2018 were used, by which the accuracy between the predicted model and in situ value was evaluated based on the root mean square error (RMSE).

\section{Results}

Multiple model optimization and calibration tests were carried out, evaluating each spectral, meteorological, topographical, geological and taxonomic variable, in order to find the optimal calibration and final list of SOC predictors. This is a long process that starts using all variables (20), then each non-contributing variable to improve the model is discarded, until the best model and combination of variables is found. Figure 6 shows the results of the three most relevant models, with the highest determination coefficients $\left(R^{2}\right)$, and at the same time the lowest RMSE. The algorithm sorts the evaluated variables according to their relative importance so that the user can locate and choose to discard one or more variables. Tree nodes between 400 and 1000 was probed, with 400 tree nodes the $R^{2}$ value was low and the RMSE is not stable. With 1000 tree nodes a highest value $R^{2}$ was obtained with a stable RMSE, with 500 tree nodes the results were the same, so in order to optimize the model on this study 500 tree nodes were used.

The best performing models with highest accuracy are presented on Fig. 6. The predictors GU, T, Pr, Tx, Elev and Asp are common on the three models (A, B and C). The model A was based on 9 predictors noticeably improved the model, reducing the RSME and reach a $R^{2}$ of 0.82. In the models $B$ and model $C$ the $\mathrm{R}^{2}$ decrease, variables such as NDVI, NDWI, SAVI, EVI2 vegetation indices decreased the performance of the model (model C). Variables such as VARIG, SLP, NDVI, NDWI, SAVI, EVI2, WDRVI, NDSI, NDMI, NBR, NBR2 were discarded due to their minor statistical relevance for the prediction. These variables do not have a strong link established with SOC. While other studies have shown results with NDVI index as a SOC predictor [93-95], the index is shown less relevant for the complex Andean ecosystem.

The correlation matrix of model A predictors variables is shown in Table 4. Where, a natural correlation between SOC (in weight \%) and SOC (in $\mathrm{Mg} / \mathrm{ha}$ ) is observed, the correlation between SOC with Soil Taxonomy and Precipitation also stands out. On the other hand, there is a negative correlation between SOC and Average annual temperature. Figure 6 indicates the relative importance of the predictive variables according to their contribution to the performance of the SOC prediction in model A (see advanced statistics in Table 5). For 185 OOB testing data points, a RMSE of $1.72 \%$ and a $\mathrm{R}^{2}$ of 0.82 for the predictive model of SOC \% were obtained. SOC in $\mathrm{Mg} / \mathrm{ha}$ is not proportional to SOC \%, as the unit conversion depends on the soil bulk density, so the model A was used but with the SOC dataset values in units of $\mathrm{Mg} / \mathrm{ha}$. The results were a RMSE of $25.8 \mathrm{Mg} / \mathrm{ha}$ and a $\mathrm{R}^{2}$ of 0.77 . Finally, the SOC mapping in the profile $0-30 \mathrm{~cm}$, was obtained in units of $\%$ and then in units of $\mathrm{Mg} / \mathrm{ha}$ see Fig. 7.

Geological unit, soil taxonomy, precipitation and elevation were the variables that provided the most information in the SOC prediction model. This is in line with the studies of dynamics in SOC and its decomposition [96-99], where, environment and soils properties like soil texture and structure, precipitation, and average temperature have a great impact. To identify the SOC variations is a difficult task, in particular on sites without human intervention. The SOC variations can be related to variables from biological and pedogenic processes [100], explained by the high importance of geological unit and soil taxonomy. In short, it was possible to find that the variables that drive the SOC prediction model maintain a physical-chemical relationship with the dynamics of carbon sequestration $[8,98]$, where, the soil geology, the composition, soil properties, surface soil conditions and topographic factors as well as the climate environment play a very important role. Also, it allows us to know the 
Table 4 Correlation matrix based on Pearson correlation coefficient of model A predictors

\begin{tabular}{|c|c|c|c|c|c|c|c|c|c|c|c|}
\hline & Elev & $T x$ & GU & LSF & Asp & $\mathrm{BI}$ & $\mathrm{TBrT}$ & $\operatorname{Pr}$ & $T$ & SOC $\%$ & $\mathrm{SOCMg} / \mathrm{ha}$ \\
\hline Elev & 1.00 & & & & & & & & & & \\
\hline Tx & -0.11 & 1.00 & & & & & & & & & \\
\hline GU & 0.24 & -0.28 & 1.00 & & & & & & & & \\
\hline LSF & -0.30 & 0.06 & -0.29 & 1.00 & & & & & & & \\
\hline Asp & -0.15 & -0.13 & 0.07 & 0.08 & 1.00 & & & & & & \\
\hline $\mathrm{Bl}$ & 0.32 & -0.14 & 0.27 & -0.28 & -0.11 & 1.00 & & & & & \\
\hline TBrT & -0.09 & 0.02 & 0.16 & -0.23 & -0.29 & 0.46 & 1.00 & & & & \\
\hline $\operatorname{Pr}$ & -0.12 & -0.33 & 0.17 & -0.17 & 0.05 & 0.18 & 0.17 & 1.00 & & & \\
\hline T & -0.01 & 0.18 & -0.24 & 0.15 & 0.004 & -0.15 & -0.18 & -0.47 & 1.00 & & \\
\hline SOC $\%$ & 0.001 & -0.43 & 0.25 & -0.05 & 0.09 & 0.12 & -0.003 & 0.50 & -0.26 & 1.00 & \\
\hline SOC Mg/ha & 0.02 & -0.30 & 0.20 & -0.05 & 0.07 & 0.11 & 0.01 & 0.39 & -0.17 & 0.88 & 1.00 \\
\hline
\end{tabular}

Table 5 Advanced statistics for model prediction of SOC (Model A)-Model error measures from the OOB testing data

\begin{tabular}{lrlrrr}
\hline & RMSE & $\mathbf{R}^{2}$ & \multicolumn{1}{c}{ MSE } & MAD & MAPE \\
\hline SOC \% & 1.72 & 0.82 & 2.96 & 1.20 & 0.14 \\
SOC in Mg/ha & 25.78 & 0.77 & 664.82 & 18.60 & 0.17 \\
\hline
\end{tabular}

degree of importance of each variable around the amount of SOC prediction and sequestration (see Fig. 6).

One spectral index, the Bare Soil Index (BI), was found relevant in the prediction model, with high values of $\mathrm{BI}$ indicating a decrease of SOC content. The same effect was noted with values of the soil erosion factor (LS

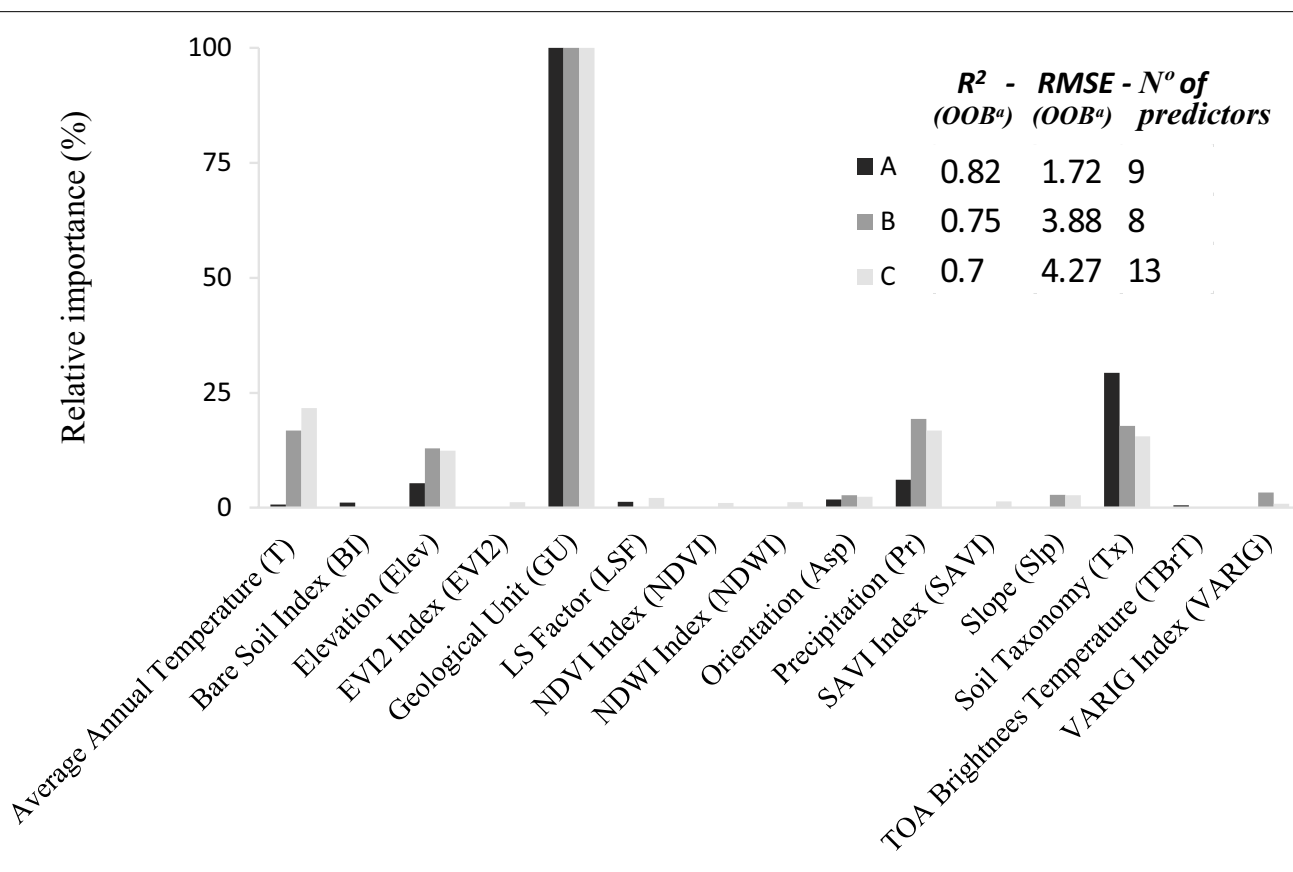

Predictive variable

Fig. 6 Relevant model calibration results in SOC (in weight \%) prediction. Relative importance of the models' prediction variables is shown, giving $100 \%$ to the most important predictor and relative importance (in \%) for each other variable in the respective model [31]. Statistical performance indicators are shown. ${ }^{\mathrm{a}} \mathrm{OOB}$ testing data (185 samples) 


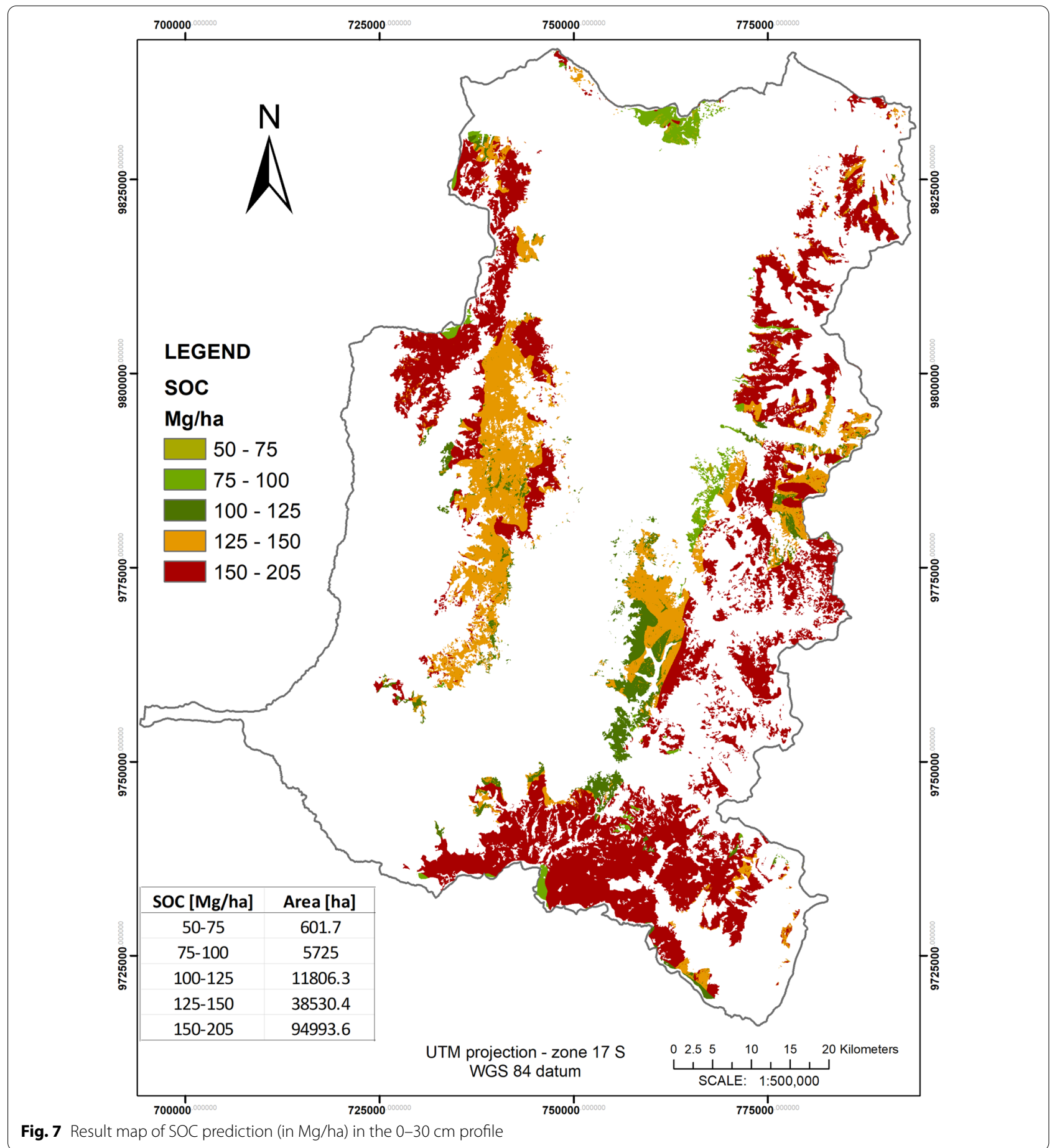

Factor). It can explained by the fact that when the better conserved the soil, it has more organic matter, better carbon storage and better water regulation [101]. Also soil erosion by wind and water, subsequent sediment transport, and depositional processes may lead to soil organic carbon (SOC) loss [86]. Since the scale of the variables geological unit and taxonomy have a rather low spatial resolution, predictors variables such as $\mathrm{BI}$ index derived from satellite images and derived from DEM could increase the resolution of the spatial prediction. However, these variables show only a minor relative importance to the main variable, 1.17 and $1.32 \%$, respectively. 
Figure 7 shows the SOC map obtained from Model A, showing that the largest percentage (over 57\%) of the study area, contains high concentrations of SOC, between 150 and $205 \mathrm{Mg} / \mathrm{ha}$ and lowest SOC values were between 50 and $75 \mathrm{Mg} / \mathrm{ha}$, principally on Andosols and Inceptisols soils. The high SOC content found is larger compared to SOC content values in pristine soils in other world areas, while the low SOC content values are similar to the content values in intervened soils [102]. Processes related to erosion, decomposition and leaching decrease the SOC content $[86,103]$.

An independent validation test of the Model A with the additional dataset of 29 points is performed. Figure 8 shows the validation statistics for both SOC predictions in $\%$ and $\mathrm{Mg} / \mathrm{ha}$ for the 29-points. Through the additional field sampling performed, it can be observed that the results of both models are good, although the SOC (\%) based prediction model has less error. This could be explained due to the complexity to account for the soil bulk density by the prediction model. Soil bulk density is a relevant property to obtain more correct $\mathrm{SOC}$ values in $\mathrm{Mg} / \mathrm{ha}$ on an area basis $[8,50,51]$, but a uncertainty error by the soil bulk density can be added [104]. Figure 8 resumes the results based on errors values, obtaining fairly good values of relative RMSE in both cases (16.1 and $19.5 \%$ ). Also, we can note that high concentrations of SOC would be more difficult to predict. It would be explained due to the soils with high in organic carbon are also the most affected by the variability in soil bulk density [105].

\section{Discussion}

The results of the RF models selected expose the most relevant SOC predictors from a group of 20 variables, carefully chosen for their possible relationship with SOC sequestration. A model with nine variables predicting SOC storage was calibrated with a good accuracy. The most important SOC predictors from the model are given by geological unit, soil taxonomy, precipitation and elevation. This was expected, considering the welldocumented classes of soils present in the herbaceous páramo ecosystem based on the Geological unities (31) and the soil taxonomy classification (Andosols, Entisols, Histosols, Inceptisols and Mollisols). Environmental factors on the land surface moderates the exchange of water, energy, and greenhouse gases between the land and the atmosphere [106, 107]. In the páramo region the dynamic SOC storage is known to linearly increase with precipitation intensity [108]. A higher precipitation provides moisture in soils and contributes in its amount of water retention, influenced by the type of soil and vegetation, among others. Jenny [106] and Adhikari et al. [107] found that topographic variables had a higher influence at finer scales, whereas climatic variables were more important at coarser scales. Therefore, due to the large study area of $1667.6 \mathrm{~km}^{2}$ and large elevation range between 2303 and $4501 \mathrm{~m}$ a.s.l, it is possible to explain the importance of elevation and another topographic predictors for the resulting model.

Other studies on SOC estimations provided equal value ranges and accuracies. A SOC case study in Cameroon, on 3 horizons $(0-15 \mathrm{~cm}, 15-30 \mathrm{~cm}$ and $30-100 \mathrm{~cm})$ of soil used a hybrid machine learning modelling and legacy soil data, provided $R^{2}$ values between 0.52 and 0.67 for SOC ranges between 11 and $210 \mathrm{Mg} / \mathrm{ha}$ at the $0-30 \mathrm{~cm}$ horizon. In the case of study areas with large elevation ranges, the elevation and the weather variables precipitable water vapor and rain are typically linked with SOC [109]. In a Chinese case study with great variety of vegetation and soil types and distribution patterns, $67 \%$ of
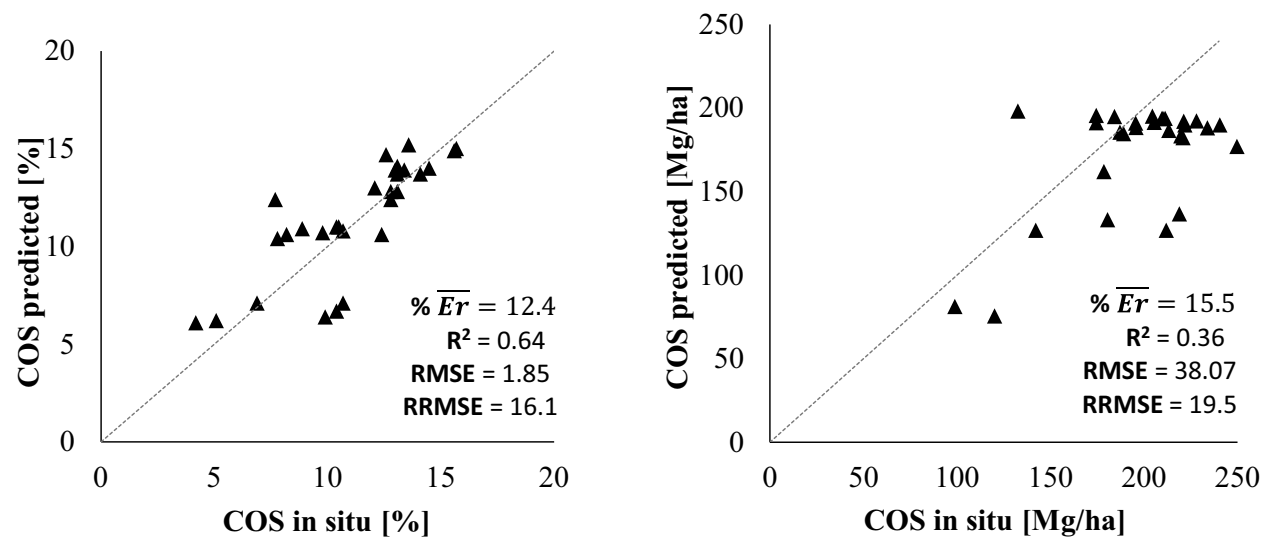

Fig. 8 Validation of the Model A prediction model for SOC expressed in weight \% (left) and in Mg/ha (right) based on an independent randomly sampled dataset (29-points). The 1:1 line is shown 
SOC variation was explained by DEM and NDVI parameters through an artificial neural network combined with kriging (ANN- kriging), and regression tree (RT) models [28]. A north American case study in the state of Indiana showed the highest prediction accuracy $(R=0.75)$ using ordinary kriging over a study area with low variation in elevation [24]. In general, hybrid spatial models applied based on ML algorithms including auxiliary variables (slope, elevation, Topographic Wetness Index (TWI), among others) could increase the accuracy of predictions, but if the selection of variables is not appropriate for the study area model predictions might be rather poor [27].

Including remote sensing techniques for the prediction of SOC has led to poor to good results $\left(R^{2}=0.23-0.67\right)$ [34], where spectral information from Environmental Mapping and Analysis Program (EnMAP) and Sentinel-2 sensors have shown the best results $[67,68]$. In this work, L8 imagery was used and processed to correct and eliminate clouds cover, obtaining spectral information for the entire study area, without the necessity of eliminate sections for cloudiness concept. The rich database used in this study, with $500 \mathrm{SOC}$ data point trying to encompass all soil heterogeneity, made it possible to obtain enough information to calibrate the RFR model with high accuracy. Moreover, terrain knowledge of the study area was fundamental to prioritize the election of variables to be evaluated as a SOC predictors.

Several remote sensing techniques that varying depending on their spatial, spectral, temporal and radiometric resolution and the platforms that are mounted on (spaceborne platforms, airborne platforms and unmanned aerial systems) can help to quantify the soil carbon sequestration [34]. Gholizadeh et al. [110] found that Red and NIR bands, also spectral indices BI, SAVI among others provide the strongest correlations with SOC. Which agrees with the results of this study, where the BI was found as SOC predictor, so too the TOA Brightness Temperature.

Only few SOC studies focus were performed in the páramo region $[39,111]$. Due to the soil chemistry of these alpine tundra ecosystems they are known to contain very high carbon in the soil $[7,58]$, but predicting the SOC stock and its distribution remains a complex task. A large sampling density is in favor for RF regression for SOC mapping but due to some limited access of certain areas a homogeneous sampling over the entire herbaceous páramo was not possible. This was the reason to use a stratification of sampling units as a sample design, avoiding sampling points in the edges, to reduce errors by delimitation of stratification or precision by GPS. The limitation on this sampling design is the lower density of sample data points within zones difficult to access. On the other hand, areas with less accessibility are less exposed to anthropic interventions, therefore SOC alterations in these areas are expected to be low.

Erosion, transport, and depositional processes redistribute landscape SOC [86], whence in this study, the topographic factor and the use of remote sensors were widely analyzed to decrease errors by produced by these environmental phenomena in the model. Further, this study analyzed the link and predictive power of soil (cover) variables, using remotely sensed vegetation indices, including also the TOA Brightness Temperature, in addition to classic SOC predictors. Combined with $\mathrm{L} 8$ (OLI and TIRS sensors) spectral data, the RFR model based on a wide set of climatologic, geophysical and biophysical predictor variables resulted in good predictions.

A future extension of this work would be to use other satellite sensors such as Sentinel-2 [112], based on the automatic products such as Leaf Area Index (LAI), Fractional Vegetation Cover (FVC), Leaf Chlorophyll Content $(\mathrm{Cab})$ and Canopy Water Content (CWC) among others. Hence, biophysical variables, available at higher spatial resolution, could be further used to explain a possible linking with the SOC storage capacity of the herbaceous páramo soils.

\section{Conclusions}

In this research, a soil organic carbon multi-predictor model for the complex Andean páramo area was calibrated with an accuracy level of $82 \%$ for SOC in weight $\%$ and $77 \%$ for SOC in $\mathrm{Mg} / \mathrm{ha}$. The spatial estimation of $\mathrm{SOC}$ is challenging to achieve for complex areas due to effects of climate, topographical variability and geological diversity, among others. By optimizing a Random Forest (RF) automatic learning algorithm, nine environmental variables related to the dynamics of SOC sequestration were selected. The variables geological unit, soil taxonomy, precipitation, height, orientation, LS factor, BI index, average annual temperature and TOA Brightness Temperature were found to have great relevance in the quantification of SOC.

The prediction of SOC is strongly driven by the geological unit and the soil taxonomy, followed by the mean yearly precipitation and elevation. Considering the terrain topographical complexity to be studied, as well as the geological heterogeneity, variables with better spatial resolution may improve the resolution for SOC distribution results. This is the case of the variables obtained through the OLI and TIRS remote sensors. Only a few spectral indices were important for SOC prediction model, i.e. the $\mathrm{BI}$ index and the TOA Brightness Temperature. Nonetheless, due to the heterogeneity of the study area, predictors 
with less relative importance for the model such as the BI index, orientation, LS Factor, average temperature and TOA Brightness Temperature helped to increase the accuracy of the RF regression model.

The use of remote sensing data for the mountainous páramo ecosystem, was challenging due to extreme weather conditions causing high percentages of cloudiness in the satellite images. For this reason, the time dedicated to image selection, treatment, and detection of cloud areas, as well as filling in was a laborious, meticulous and a critical process. Even so, the methodology used in image processing and geographic information generation was useful and it was possible to achieve valuable information for the model. The next research step for these complex environments would be to consider how to introduce alternatives where the atmospheric influence can be minimized, as is the case with RADARRadio Detection and Ranging sensors.

The proposed methodology could be used by research groups studying similar complex ecosystems, as the high Andean areas. The results of the SOC quantification and mapping in the herbaceous páramo ecosystem are of vital importance to the global objective of knowing and quantifying the $\mathrm{SOC}$ reserves. The high $\mathrm{SOC}$ values further demonstrate the importance of knowing the SOC reserves in these ecosystems, including the factors which control or affect the mineralization process on the one hand, and the soil degradation effects due to erosion, on the other hand. Moreover, the results obtained through the digital mapping of the high reserves of SOC represent a great contribution in the soil characterization of the Ecuadorian territory. This will allow to establish provincial and national regulations to prevent soil degradation in this type of ecosystem, given their importance in soil structures stabilization, water regulation and carbon storage. Such actions will further allow a better conservation and management of these valuable carbon storage ecosystems from a local towards a global perspective.

\footnotetext{
Abbreviations

SOC: Soil organic carbon; SOM: Soil organic matter; OM: Organic matter; OK: Ordinary kriging; RK: Regression kriging; UK: Universal kriging; ML: Machine learning; OLI: Operational Land Imager; TIRS: Thermal Infrared Sensor; CART : Classification and Regression Trees; RF: Random Forest; L8: Landsat 8; DEM: Digital elevation model; GloVis: Global Visualization Viewer; DN: Digital numbers; TOA: Top of the atmosphere; NBR2: Normalized Burn Ratio 2; SAVI: Soil-Adjusted Vegetation Index; WDRVI: Wide Dynamic Range Vegetation Index; EVI2: Enhanced Vegetation Index 2; NDWI: Normalized Difference Water Index; VARIg: Visible Atmospherically Resistant Vegetation Index green; NDSI: Normalized Difference Snow Index; BI: Bare Soil Index; NDMI: Normalized Difference Moisture Index; NBR: Normalized Burn Ratio; NBR2: Normalized Burn Ratio 2; LS Factor: Slope Length and Steepness Factor; TWI: Topographic Wetness Index; RMSE: Root mean square error; R2: Determination coefficient; MSE: Mean Squared Error; MAD: Mean Absolute Deviation; MAPE: Mean Absolute Percentage Error; SSY: Total sum of squares; SSE: Sum of squares of residuals; OOB: Out of Bag.
}

\section{Acknowledgements}

The study is supported by "Soil Organic Carbon Evaluation and Sequestration in Ecuadorian Páramo Ecosystems" (SOCEPE) project funding by the National University of Chimborazo, Ecuador, who provided the SOC dataset used on this study; and Secretariat of Higher Education, Science, Technology and Innovation (SENESCYT), Ecuador. The authors thank the Ministery of the Environment of Ecuador for issuing the research permit (N.017-2019-IC-FLO-FAU-DNB/ MAE).

\section{Authors' contributions}

All the authors have made substantial contribution towards the successful completion of this manuscript. JA: Methodology, Formal analysis, Writing, Review and Editing; CM: Conceptualization, Supervision; VG: Conceptualization, Supervision; CJ: Methodology; JS: Supervision; NP: Review and Editing; SVW: Supervision, Review and Editing; JD: Supervision, Review and Editing. All authors read and approved the final manuscript.

\section{Funding}

Not applicable.

\section{Availability of data and materials}

The datasets during and/or analyzed during the current study available from the corresponding author on reasonable request.

\section{Declarations}

Ethics approval and consent to participate

Not applicable.

\section{Consent for publication}

Not applicable.

\section{Competing interests}

The authors declare that they have no competing interests.

\section{Author details}

${ }^{1}$ Image Processing Laboratory (IPL), University of Valencia, 46980 Paterna, Valencia, Spain. ${ }^{2}$ Faculty of Engineering, National University of La Plata, B1900TAG La Plata, Argentina. ${ }^{3}$ Faculty of Engineering, National University of Chimborazo, Riobamba 060150, Ecuador. ${ }^{4}$ Faculty of Forestry and Environmental Sciences, University of Los Andes, Mérida 5101, Venezuela. ${ }^{5}$ Faculty of Science, University of Los Andes, Mérida 5101, Venezuela. ${ }^{6}$ Faculty of Natural Resources, Higher Superior Polytechnic School of Chimborazo, Riobamba 060155, Ecuador.

Received: 29 October 2020 Accepted: 12 October 2021

Published online: 24 October 2021

\section{References}

1. Jandl R, Rodeghiero M, Martinez C, Cotrufo MF, Bampa F, Wesemael B, van; Harrison, R.B., Guerrini, E.A., Richter DB; Rustad, L., et al. Current status, uncertainty and future needs in soil organic carbon monitoring. Sci Total Environ. 2014;468:376-83. https://doi.org/10.1016/j.scitotenv. 2013.08.026.

2. Lal R. Forest soils and carbon sequestration. For Ecol Manage. 2005;220:242-58. https://doi.org/10.1016/j.foreco.2005.08.015.

3. Zhou Y, Hartemink AE, Shi Z, Liang Z, Lu Y. Land use and climate change effects on soil organic carbon in North and Northeast China. Sci Total Environ. 2019;647:1230-8. https://doi.org/10.1016/j.scitotenv.2018.08. 016.

4. Grace PR, Post WM, Hennessy K. The potential impact of climate change on Australia's soil organic carbon resources. Carbon Balance Manag. 2006;1:14. https://doi.org/10.1186/1750-0680-1-14.

5. Kirschbaum MUF. Will changes in soil organic carbon act as a positive or negative feedback on global warming? Biogeochemistry. 2000;48:2151. https://doi.org/10.1023/A:1006238902976. 
6. Sommer R, Bossio D. Dynamics and climate change mitigation potential of soil organic carbon sequestration. J Environ Manage. 2014;144:83-7. https://doi.org/10.1016/j.jenvman.2014.05.017.

7. Moreno J, Yerovi F, Herrera M, Yánez D, José E. Soils from the Highlands. In: The Soils of Ecuador; 2018; pp. 79-111.

8. Lefévre C, Rekik F, Wiese L. Soil Organic Carbon: the Hidden Potential; Rome. Italy, 2017; ISBN 9789251096819.

9. Minasny B, McBratney AB, Malone BP, Lacoste M, Walter C. Quantitatively Predicting Soil Carbon Across Landscapes. In: Hartemink A, McSweeney K, editors. Soil Carbon Progress in Soil Science. Cham: Springer; 2014.

10. Siewert MB. High-resolution digital mapping of soil organic carbon in permafrost terrain using machine learning : a case study in a sub-Arctic peatland environment. Biogeosciences. 2018;15:1663-82. https://doi. org/10.5194/bg-15-1663-2018.

11. Sheikh MA, Kumar M, Bussmann RW. Altitudinal variation in soil organic carbon stock in coniferous subtropical and broadleaf temperate forests in Garhwal himalaya. Carbon Balance Manag. 2009;4:6. https://doi.org/ 10.1186/1750-0680-4-6.

12. Mena Vásconez P, Castillo A, Flores S, Hofstede R, Josse C, Lasso S, Medina G, Ochoa N, Ortiz D. Páramo. Paisaje estudiado, habitado, manejado e institucionalizado. 2011; ISBN 9789942090164. http://190. 57.147.202:90/xmlui/handle/123456789/1888

13. Choudhury BU, Fiyaz AR, Mohapatra KP, Ngachan S. Impact of Land Uses, Agrophysical Variables and Altitudinal Gradient on Soil Organic Carbon Concentration of North-Eastern Himalayan Region of India. L Degrad Dev. 2016;27:1163-74. https://doi.org/10.1002/ldr.2338.

14. Ramifehiarivo N, Brossard M, Grinand C, Andriamananjara A, Razafimbelo T, Rasolohery A, Razafimahatratra H, Seyler F, Ranaivoson N, Rabenarivo M, et al. Mapping soil organic carbon on a national scale: Towards an improved and updated map of Madagascar. Geoderma Reg. 2017;9:29-38. https://doi.org/10.1016/j.geodrs.2016.12.002.

15. Schlesinger WH, Amundson R. Managing for soil carbon sequestration: let's get realistic. Glob Chang Biol. 2019;25:386-9. https://doi.org/10. $1111 /$ gcb.14478.

16. Xu S, Sheng C, Tian C. Changing soil carbon: influencing factors, sequestration strategy and research direction. Carbon Balance Manage. 2020;15:2. https://doi.org/10.1186/s13021-020-0137-5.

17. Wiesmeier M, Urbanski L, Hobley E, Lang B, Lützow M, von; Marin-Spiotta, E., Wesemael, B. van; Rabot, E., Ließ, M., Garcia-Franco, N., et al. " Soil organic carbon storage as a key function of soils - A review of drivers and indicators at various scales " Geoderma Soil organic carbon storage as a key function of soils - A review of drivers and indicators at various scales. Geoderma. 2019;333:149-62. https://doi.org/10.1016/j.geode rma.2018.07.026.

18. McBratney AB, Mendonça Santos ML, Minasny B. On digital soil mapping. Geoderma. 2003;117:3-52. https://doi.org/10.1016/S00167061(03)00223-4.

19. Thompson JA, Kolka RK. Soil Carbon Storage Estimation in a Forested Watershed using Quantitative Soil-Landscape Modeling. Soil Sci Soc Am J. 2005;69:1086-93. https://doi.org/10.2136/SSSAJ2004.0322.

20. Arrouays D, Daroussin J, Kicin JL, Hassika P. Improving topsoil carbon storage prediction using a digital elevation model in temperate forest soils of France. Soil Sci. 1998;163:99.

21. Oliver M. Geostatistics and its application to soil science. Soil Use Manag. 1987;3:8-20. https://doi.org/10.1111/j.1475-2743.1987.tb007 03.x.

22. Wadoux AMJ, Minasny B, Mcbratney AB. Machine learning for digital soil mapping: applications, challenges and suggested solutions. EarthScience Rev. 2020;210: 103359. https://doi.org/10.1016/j.earscirev.2020. 103359.

23. .Cressie, N.; Johannesson, G. Fixed rank kriging for very large spatial data sets. J R Stat Soc Ser B. 2008, 70, 209-226, https://doi.org/10.1111/J. 1467-9868.2007.00633.X.

24. Mishra U, Lal R, Slater B, Calhoun F, Liu D, Van Meirvenne M. Predicting Soil Organic Carbon Stock Using Profile Depth Distribution Functions and Ordinary Kriging. Soil Sci Soc Am J. 2009;73:614-21. https://doi.org/ 10.2136/sssaj2007.0410.

25. Chen S, Martin MP, Saby NPA, Walter C, Angers DA, Arrouays D. Fine resolution map of top- and subsoil carbon sequestration potential in
France. Sci Total Environ. 2018;630:389-400. https://doi.org/10.1016/J. SCITOTENV.2018.02.209.

26. Mulder VL, Lacoste M, Richer-de-Forges AC, Martin MP, Arrouays D. National versus global modelling the 3D distribution of soil organic carbon in mainland France. Geoderma. 2016;263:16-34. https://doi.org/ 10.1016/J.GEODERMA.2015.08.035.

27. Tziachris P, Aschonitis V, Chatzistathis T, Papadopoulou M. Assessment of spatial hybrid methods for predicting soil organic matter using DEM derivatives and soil parameters. CATENA. 2019;174:206-16. https://doi. org/10.1016/j.catena.2018.11.010.

28. Zhao YC., Shi XZ. (2010) Spatial Prediction and Uncertainty Assessment of Soil Organic Carbon in Hebei Province, China. In: Boettinger J.L., Howell D.W., Moore A.C., Hartemink A.E., Kienast-Brown S. (eds) Digital Soil Mapping. Progress in Soil Science, vol 2. Springer, Dordrecht. https://doi.org/10.1007/978-90-481-8863-5_19

29. Dobermann, A., Simbahan, G. C. (2007): Methodology for using Secondary Information in Sampling Optimization for Making Fine-Resolution Maps of Soil Organic Carbon, in P. Lagacherie (eds.): Digital Soil Mapping, An Introductory Perspective. Developments in Soil Science. Vol. 31. Elsevier, Amsterdam, The Netherlands, pp. 167- 182. https://doi.org/10. 1016/S0166-2481(06)31013-6.

30. Hengl, T.; Heuvelink, G.B.M.; Kempen, B.; Leenaars, J.G.B.; Walsh, M.G.; Shepherd, K.D.; Sila, A.; MacMillan, R.A.; Mendes de Jesus, J.; Tamene, L.; et al. Mapping Soil Properties of Africa at $250 \mathrm{~m}$ Resolution : Random Forests Significantly Improve Current Predictions. PLoS One 2015, 10, 1-26, https://doi.org/10.1371/journal.pone.0125814.

31. Breiman L. Random Forests. Mach Learn. 2001;45:5-32. https://doi.org/ 10.1023/A:1010933404324.

32. Zhang $G$, Feng $L$, Xiao-dong $S$. Recent progress and future prospect of digital soil mapping: A review. J Integr Agric. 2017;16:2871-85. https:// doi.org/10.1016/S2095-3119(17)61762-3.

33. Veronesi F, Schillaci C. Comparison between geostatistical and machine learning models as predictors of topsoil organic carbon with a focus on local uncertainty estimation. Ecol Indic. 2019;101:1032-44. https://doi. org/10.1016/J.ECOLIND.2019.02.026.

34. Angelopoulou T, Tziolas N, Balafoutis A, Zalidis G, Bochtis D. Remote sensing techniques for soil organic carbon estimation: A review. Remote Sens. 2019;11:676. https://doi.org/10.3390/rs11060676.

35. Farley KA, Kelly EF, Hofstede RGM. Soil Organic Carbon and Water Retention after Conversion of Grasslands to Pine Plantations in the Ecuadorian Andes. Ecosystems. 2004;7:729-39. https://doi.org/10.1007/ s10021-004-0047-5.

36. Farley KA, Bremer LL, Harden CP, Hartsig J. Changes in carbon storage under alternative land uses in biodiverse Andean grasslands: Implications for payment for ecosystem services. Conserv Lett. 2013;6:21-7. https://doi.org/10.1111/j.1755-263X.2012.00267.X.

37. López S, López-Sandoval MF, Gerique A, Salazar J. Landscape change in Southern Ecuador: An indicator-based and multi-temporal evaluation of land use and land cover in a mixed-use protected area. Ecol Indic. 2020;115: 106357. https://doi.org/10.1016/j.ecolind.2020.106357.

38. McKnight JY, Harden CP, Schaeffer SM. Soil CO2 flux trends with differences in soil moisture among four types of land use in an Ecuadorian páramo landscape. Phys Geogr. 2017;38:51-61. https://doi.org/10.1080/ 02723646.2016.1256101.

39. Ließ M, Schmidt J, Glaser B. Improving the Spatial Prediction of Soil Organic Carbon Stocks in a Complex Tropical Mountain Landscape by Methodological Specifications in Machine Learning Approaches. PLoS ONE. 2016;11:1-22. https://doi.org/10.1371/journal.pone.0153673.

40. Ministerio de Ambiente del Ecuador Sistema de Clasificación de Ecosistemas del Ecuador Continental; Galeas, R., Guevara, J.E., Medina-Torres, B., CHinchero, M.Á., Herrera, X., Eds.; Quito, 2013;

41. Beltrán, K.; Salgado, S.; Cuesta, F.; León-Yánez, S.; Romoleroux, K.; Ortiz, E.; Cardenas, A.; Velástegui, A. Distribución espacial, sistemas ecológicos y caracterización florística de los páramos en el Ecuador: Quito, 2009: ISBN 9978-9940-7.

42. Ministerio de Ambiente del Ecuador Sistema de clasificación de los ecosistemas del Ecuador continental. Subsecretaría de Patrimonio Natural (a); Quito, 2012; ISBN 9788578110796.

43. Mena Vásconez, P.; Castillo, A.; Flores, S.; Hofstede, R.; Josse, C.; Lasso, S.; Medina, G.; Ochoa, N.; Ortiz, D. Páramo. Paisaje estudiado, habitado, manejado e institucionalizado; Mena Vásconez, P., Castillo, A., Flores, S., 
Hofstede, R., Josse, C., Lasso, S., Medina, G., Ochoa, N., Ortiz, D., Eds.; 2011; ISBN 9789942090164.

44. Guio Blanco CM, Brito Gomez VM, Crespo P, Ließ M. Spatial prediction of soil water retention in a Páramo landscape: Methodological insight into machine learning using random forest. Geoderma. 2018;316:100-14. https://doi.org/10.1016/j.geoderma.2017.12.002.

45. SISTEMA NACIONAL DE INFORMACIÓN DEL ECUADOR INFOPLAN. https://sni.gob.ec/inicio

46. Wadoux AMJC, Brus DJ, Heuvelink GBM. Sampling design optimization for soil mapping with random forest. Geoderma. 2019;355:113913. https://doi.org/10.1016/j.geoderma.2019.113913.

47. Al-Shammary AAG, Kouzani AZ, Kaynak A, Khoo SY, Norton M, Gates W. Soil Bulk Density Estimation Methods: A Review. Pedosphere. 2018:28:581-96. https://doi.org/10.1016/S1002-0160(18)60034-7.

48. Bateni C, Ventura M, Tonon G, Pisanelli A. Soil carbon stock in olive groves agroforestry systems under different management and soil characteristics. Agrofor Syst. 2019;7:1-11. https://doi.org/10.1007/ s10457-019-00367-7.

49. Tonon, G.; Monti, B.; Lenzi, D.; Tattini, F.; Panzacchi, P. Comparison of non-invasive indirect method and trenching to partitioning soil respiration in a hardwood temperate forest. In Proceedings of the EGU General Assembly Conference Abstracts; Vienna, Austria, 2010; p. 14300.

50. Bongiorno G, Bünemann EK, Oguejiofor CU, Meier J, Gort G, Comans R, Mäder P, Brussaard L, de Goede R. Sensitivity of labile carbon fractions to tillage and organic matter management and their potential as comprehensive soil quality indicators across pedoclimatic conditions in Europe. Ecol Indic. 2019;99:38-50. https://doi.org/10.1016/j. ecolind.2018.12.008.

51. Lee J, Hopmans JW, Rolston DE, Baer SG, Six J. Determining soil carbon stock changes: Simple bulk density corrections fail. Agric Ecosyst Environ. 2009;134:251-6. https://doi.org/10.1016/j.agee.2009.07.006.

52. USGS USGS GloVis.

53. Mena, P.; Josse, C.; Medina, G. Los suelos de los Páramos del Ecuador; 2000; ISBN 9978045910.

54. USGS USGS Landsat Missions-USGS EROS GCP Library.

55. IGM Geoportal IGM

56. Harris Geoespacial Solutions. Harris Geoespacial solutions [Internet]. Harris Geospatial Solut. Inc. 2014. Available from: https://www.I3har risgeospatial.com/Support/Maintenance/ArtMID/10427/ArticleID/ 16174/ENVI-51

57. USGS Landsat 8 (L8) Data Users Handbook; 2019; USGS. Landsat 8 (L8) Data Users Handbook [Internet]. U.S. Geol. Surv. 2019. Available from: https://www.usgs.gov/media/files/landsat-8-data-users-handbook

58. Podwojewski, P.; Poulenard, J. Paramos soils. Encycl. Soil Sci. 2004, 3068. https://core.ac.uk/download/pdf/39843915.pdf

59. Croft H, Kuhn NJ, Anderson K. On the use of remote sensing techniques for monitoring spatio-temporal soil organic carbon dynamics in agricultural systems. CATENA. 2012;94:64-74. https://doi.org/10. 1016/j.catena.2012.01.001.

60. Hartemink, A.E.; McSweeney, K. Soil carbon; Springer International Publishing Switzerland: Madison, Wisconsin, 2014; ISBN 9783319040837.

61. Zhang K, Dang H, Zhang Q, Cheng X. Soil carbon dynamics following land-use change varied with temperature and precipitation gradients: evidence from stable isotopes. Glob Chang Biol. 2015;21:2762-72. https://doi.org/10.1111/gcb.12886.

62. Mcknight, J.Y. Linking soil moisture and carbon-cycle processes in two understudied terrestrial ecosystems: Ecuadorian páramo grasslands and constructed agricultural wetlands. 2015, 135. PhD diss., University of Tennessee. https://trace.tennessee.edu/utk_graddiss/3352.

63. Plummer S, Arino O, Simon M, Steffen W. Establishing A Earth Observation Product Service For The Terrestrial Carbon Community: The Globcarbon Initiative. Mitig Adapt Strateg Glob Chang. 2006;1 1:97-111. https://doi.org/10.1007/s11027-006-1012-8.

64. Ladoni M, Bahrami HA, Alavipanah SK, Norouzi AA. Estimating soil organic carbon from soil reflectance: a review. Precis Agric. 2010;11:8299. https://doi.org/10.1007/s11119-009-9123-3.

65. Castaldi F, Palombo A, Santini F, Pascucci S, Pignatti S, Casa R. Evaluation of the potential of the current and forthcoming multispectral and hyperspectral imagers to estimate soil texture and organic carbon.
Remote Sens Environ. 2016;179:54-65. https://doi.org/10.1016/j.rse. 2016.03.025.

66. Gomez C, Viscarra Rossel RA, McBratney AB. Soil organic carbon prediction by hyperspectral remote sensing and field vis-NIR spectroscopy: An Australian case study. Geoderma. 2008;146:403-11. https://doi.org/ 10.1016/j.geoderma.2008.06.011.

67. Mirzaee S, Ghorbani-Dashtaki S, Mohammadi J, Asadi H, Asadzadeh F. Spatial variability of soil organic matter using remote sensing data. CATENA. 2016;145:118-27. https://doi.org/10.1016/j.catena.2016.05.023.

68. Steinberg A, Chabrillat S, Stevens A, Segl K, Foerster S. Prediction of common surface soil properties based on Vis-NIR airborne and simulated EnMAP imaging spectroscopy data: Prediction accuracy and influence of spatial resolution. Remote Sens. 2016;8:613. https://doi. org/10.3390/rs8070613.

69. Vaudour E, Gomez C, Fouad Y, Lagacherie P. Sentinel-2 image capacities to predict common topsoil properties of temperate and Mediterranean agroecosystems. Remote Sens Environ. 2019;223:21-33. https://doi.org/ 10.1016/j.rse.2019.01.006

70. Rouse JW, Hass RH, Schell JA, Deering DW. Monitoring vegetation systems in the great plains with ERTS. In: Proceedings of the Third Earth Resources Technology Satellite (ERTS) symposium. NASA special publication; 1974. pp. 309-317.

71. Huete AR. A soil-adjusted vegetation index. Remote Sens Environ 1988;25:295-309. https://doi.org/10.1016/0034-4257(88)90106-X.

72. Ayala-Izurieta J, Márquez C, García V, Recalde-Moreno C, RodríguezLlerena M, Damián-Carrión D. Land cover classification in an ecuadorian mountain geosystem using a random forest classifier, spectral vegetation indices, and ancillary geographic data. Geosciences. 2017;7:34. https://doi.org/10.3390/geosciences7020034.

73. Gitelson A. Wide dynamic range vegetation index for remote quantification of biophysical characteristics of vegetation. J Plant Physiol. 2004;161:165-73. https://doi.org/10.1078/0176-1617-01176.

74. Jiang Z, Huete AR, Didan K, Miura T. Development of a two-band enhanced vegetation index without a blue band. Remote Sens Environ. 2008;112:3833-45. https://doi.org/10.1016/j.rse.2008.06.006.

75 McFeeters SK. The use of the Normalized Difference Water Index (NDWI) in the delineation of open water features. Int J Remote Sens. 1996:17:1425-32. https://doi.org/10.1080/01431169608948714.

76. Cammarano D, Fitzgerald GJ, Casa R, Basso B. Assessing the robustness of vegetation indices to estimate wheat $\mathrm{n}$ in mediterranean environments. Remote Sens. 2014;6:2827-44. https://doi.org/10.3390/rs604 2827.

77. Gitelson AA, Kaufman YJ, Stark R, Rundquist D. Novel algorithms for remote estimation of vegetation fraction. Remote Sens Environ. 2002;80:76-87. https://doi.org/10.1016/50034-4257(01)00289-9.

78. Takeuchi W, Yasuoka Y. Development of normalized Vegetation, soil and water indices derived from satellite remote sensing data. J Japan Soc Photogramm Remote Sens. 2004;43:7-19. https://doi.org/10.4287/jsprs. 43.6_7.

79. Chen W, Liu L, Zhang C, Wang J, Wang J, Pan Y. Monitoring the seasonal bare soil areas in Beijing using multi-temporal TM images. In: Proceedings of the IGARSS 2004. 2004 IEEE International Geoscience and Remote Sensing Symposium; 5AD; pp. 3379-3382.

80. Hislop S, Jones S, Soto-berelov M, Skidmore A, Id AH, Nguyen TH. Using landsat spectral indices in time-series to assess wildfire disturbance and recovery. Remote Sens. 2018;10:460. https://doi.org/10.3390/rs100 30460.

81. Wilson EH, Sader SA. Detection of forest harvest type using multiple date of Landsat Tm imagery. Remote Sens Environ. 2002;80:385-96. https://doi.org/10.1016/S0034-4257(01)00318-2.

82. Key CH, Benson NC. Landscape Assessment: Ground measure of severity, the Composite Burn Index; and Remote sensing of severity, the Normalized Burn Ratio. In: Lutes D, Keane R, Caratti J, Key C, Benson N, Sutherland S, Gangi L, eds. FIREMON: Fire Effects Monitoring and Inventory System. USDA Forest Service, Rocky Mountain Research Station, Ogden, UT, 2006; Vol. 4, p. LA 1-LA 51.

83. Storey EA, Stow DA, O'Leary JF. Assessing postfire recovery of chamise chaparral using multi-temporal spectral vegetation index trajectories derived from Landsat imagery. Remote Sens Environ. 2016;183:53-64. https://doi.org/10.1016/j.rse.2016.05.018. 
84. Van Bemmelen JM, Über die Bestimmung des Wassers, des Humus, des Schwefels, der in den collö̈dalen Silikaten gebundenen Kieselsäure, des Mangans usw im Ackerboden; Die Landwirtschaftlichen VersuchsStationen. 1890; Vol. 37. p. 277.

85. Kuo P-F, Huang T-E, Putra GIB. Comparing kriging estimators using weather station data and local greenhouse sensors. Sensors. 1853;2021:21. https://doi.org/10.3390/s21051853.

86. Oliver MA, Webster R. Kriging: a method of interpolation for geographical information systems. 2007; 4: 313-332, https://doi.org/10.1080/ 02693799008941549

87. Olson KR, Al-Kaisi M, Lal R, Cihacek L. Impact of soil erosion on soil organic carbon stocks. J Soil Water Conserv. 2016;71:61A-67A. https:// doi.org/10.2489/jswc.71.3.61A.

88. Panagos P, Borrelli P, Meusburger K. A new European slope length and steepness factor (LS-factor) for modeling soil erosion by water. Geosci. 2015;5:117-26. https://doi.org/10.3390/geosciences5020117.

89. Desmet PJJ, Govers G. A GIS procedure for automatically calculating the USLE LS factor on topographically complex landscape units. J. Soil Water Conserv. 1996, 51, 427-433. https://www.jswconline.org/conte $n t / 51 / 5 / 427 . s h o r t$

90. USDA; NRCS Claves para la Taxonomía de Suelos; 2014; https://www. nrcs.usda.gov/Internet/FSE_DOCUMENTS/nrcs142p2_051546.pdf

91. Loh W-Y. Fifty years of classification and regression trees. Int Stat Rev. 2014;82:329-48. https://doi.org/10.1111/insr.12016.

92. Breiman L, Friedman J, Olshen R, Stone C. Classification and Regression Trees; 1st ed. Boca Raton, 1984; ISBN 9781315139470. https://doi.org/ $10.1201 / 9781315139470$

93. Salford Systems-Minitab Company Improve Your Regression Models: MARS, Gradient, and Random Forest. https://www.salford-systems.com/ resources

94. Mondal A, Khare D, Kundu S, Mondal S, Mukherjee S, Mukhopadhyay A. Spatial soil organic carbon (SOC) prediction by regression kriging using remote sensing data. Egypt J Remote Sens Sp Sci. 2017;20:61-70. https://doi.org/10.1016/j.ejrs.2016.06.004.

95 Burnham JH, Sletten RS. Spatial distribution of soil organic carbon in northwest Greenland and underestimates of high Arctic carbon stores. Global Biogeochem Cycles. 2010. https://doi.org/10.1029/2009GB0036 60.

96. Kunkel ML, Flores AN, Smith TJ, McNamara JP, Benner SG. A simplified approach for estimating soil carbon and nitrogen stocks in semi-arid complex terrain. Geoderma. 2011;165:1-11. https://doi.org/10.1016/j. geoderma.2011.06.011.

97 Lal R. Soil carbon sequestration impacts on global climate change and food security. Science. 2004;304:1623-7. https://doi.org/10.1126/scien ce.1097396.

98. Xu X, Shi Z, Li D, Rey A, Ruan H, Craine JM, Liang J, Zhou J, Luo Y. Geoderma Soil properties control decomposition of soil organic carbon: Results from data-assimilation analysis. Geoderma. 2016;262:235-42. https://doi.org/10.1016/j.geoderma.2015.08.038.

99. Stockmann U, Adams MA, Crawford JW, Field DJ, Henakaarchchi N, Jenkins M, Minasny B, McBratney AB, Courcelles V, Singh K, et al. The knowns, known unknowns and unknowns of sequestration of soil organic carbon. Agric Ecosyst Environ. 2013;164:80-99. https://doi.org/ 10.1016/j.agee.2012.10.001.
100. Chartin C, Stevens A, Goidts E, Krüger I, Carnol M, van Wesemael B. Mapping Soil Organic Carbon stocks and estimating uncertainties at the regional scale following a legacy sampling strategy (Southern Belgium, Wallonia). Geoderma Reg. 2017;9:73-86. https://doi.org/10. 1016/j.geodrs.2016.12.006.

101. Tan ZX, Lal R, Smeck NE, Calhoun FG. Relationships between surface soil organic carbon pool and site variables. Geoderma. 2004;121:187-95. https://doi.org/10.1016/j.geoderma.2003.11.003.

102. Hofstede R. Health state of Páramos: an effort to correlate science and practice. Lyonia a J Ecol Appl. 2004;6:61-73.

103. Andriulo A, Galantini J, Studdert G, Sasal M, Wilson M, Basanta M, Sánchez M, Gudelj V, Irizar A, Restovich S. Existencias de carbono orgánico edáfico bajo diferentes usos y tipos de suelo. In: Proceedings of the XIX Congreso Latinoamericano de la Ciencia del suelo and XXIII Congreso Argentino de la Ciencia del Suelo; 2012.

104. Lal R. Residue management, conservation tillage and soil restoration for mitigating greenhouse effect by $\mathrm{CO}$, -enrichment. Soil Tillege Res. 1997;43:81-107. https://doi.org/10.1016/S0167-1987(97)00036-6.

105. Walter K, Don A, Tiemeyer B, Freibauer A. Determining soil bulk density for carbon stock calculations: a systematic method comparison. Soil Sci Soc Am J. 2016;80:579-91. https://doi.org/10.2136/sssaj2015.11.0407.

106. Hiederer R, Köchy M. Global Soil Organic Carbon Estimates and the Harmonized World Soil Database; EUR 25225 EN. Publications Office of the EU, Luxembourg 2011; ISBN 9789279231087.

107. Jenny H. Factors of Soil Formation: A System of Quantitative Pedology. New York: McGraw Hill; 1941.

108. Adhikari K, Mishra U, Owens PR, Libohova Z, Wills SA, Riley WJ, Hoffman FM, Smith DR. Importance and strength of environmental controllers of soil organic carbon changes with scale. Geoderma. 2020;375: 114472. https://doi.org/10.1016/j.geoderma.2020.114472.

109. Lazo PX, Mosquera GM, McDonnell JJ, Crespo P. The role of vegetation, soils, and precipitation on water storage and hydrological services in Andean Páramo catchments. J Hydrol. 2019;572:805-19. https://doi. org/10.1016/j.jhydrol.2019.03.050.

110. Silatsa FBT, Yemefack M, Tabi FO, Heuvelink GBM, Leenaars JGB. Assessing countrywide soil organic carbon stock using hybrid machine learning modelling and legacy soil data in Cameroon. Geoderma. 2020;367: 114260. https://doi.org/10.1016/j.geoderma.2020.114260.

111. Gholizadeh A, Žižala D, Saberioon M, Borůvka L. Soil organic carbon and texture retrieving and mapping using proximal, airborne and Sentinel-2 spectral imaging. Remote Sens Environ. 2018;218:89-103. https://doi. org/10.1016/J.RSE.2018.09.015.

112. Montes CR, Ramos Miras JJ, San José Wery AM, Montes-Pulido CR, Ramos-Miras JJ, San José-Wery AM. Estimation of soil organic carbon (SOC) at different soil depths and soil use in the Sumapaz paramo, Cundinamarca - Colombia. Acta Agronómica 2016; 66: 95-101. https:// doi.org/10.15446/acag.v66n1.53171

113. ESA Sentinel-2 User Handbook. 2015; https://sentinel.esa.int/docum ents/247904/685211/Sentinel-2_User_Handbook

\section{Publisher's Note}

Springer Nature remains neutral with regard to jurisdictional claims in published maps and institutional affiliations.
Ready to submit your research? Choose BMC and benefit from:

- fast, convenient online submission

- thorough peer review by experienced researchers in your field

- rapid publication on acceptance

- support for research data, including large and complex data types

- gold Open Access which fosters wider collaboration and increased citations

- maximum visibility for your research: over 100M website views per year

At BMC, research is always in progress.

Learn more biomedcentral.com/submissions 